\title{
Production and Evaluation of Novel Exogenous Phytase Enzymes Using Several Testing Variables
}

Ashley Marie Evans

West Virginia University

Follow this and additional works at: https://researchrepository.wvu.edu/etd

\section{Recommended Citation}

Evans, Ashley Marie, "Production and Evaluation of Novel Exogenous Phytase Enzymes Using Several Testing Variables" (2012). Graduate Theses, Dissertations, and Problem Reports. 4851.

https://researchrepository.wvu.edu/etd/4851

This Thesis is protected by copyright and/or related rights. It has been brought to you by the The Research Repository @ WVU with permission from the rights-holder(s). You are free to use this Thesis in any way that is permitted by the copyright and related rights legislation that applies to your use. For other uses you must obtain permission from the rights-holder(s) directly, unless additional rights are indicated by a Creative Commons license in the record and/ or on the work itself. This Thesis has been accepted for inclusion in WVU Graduate Theses, Dissertations, and Problem Reports collection by an authorized administrator of The Research Repository @ WVU. For more information, please contact researchrepository@mail.wvu.edu. 
Production and Evaluation of Novel Exogenous Phytase Enzymes

Using Several Testing Variables

Ashley Marie Evans

Thesis submitted to the

Davis College of Agriculture, Natural Resources, and Design

at

West Virginia University

in partial fulfillment of the requirements

for the degree of

Master of Science

in

Nutrition and Food Science

Joseph S. Moritz, Ph.D., Chair

Janet Tou, Ph.D

Marlon Knights, Ph.D

Division of Animal and Nutritional Sciences

Morgantown, West Virginia

2012

Keywords: phytase, enzyme efficacy, product testing, methodology, non-phytate phosphorus, broiler performance

Copyright 2012 Ashley Marie Evans 


\section{ABSTRACT \\ Production and Evaluation of Novel Exogenous Phytase Enzymes Using Several Testing Variables \\ Ashley M. Evans}

Broiler chickens reared in the United States are mainly fed corn-soybean based diets. Most of the phosphorus in these diets is bound to a molecule called phytate; this source of phosphorus is unavailable to the bird because they lack adequate amount of endogenous phytase enzyme. Since the 1990's exogenous phytase enzymes have been incorporated in broiler diets to liberate the phytate-bound phosphorus. These enzymes must be able to resist thermal denaturation associated with pelleting and maintain high efficacy in the bird. Most of the literature focuses on single aspects of phytase efficacy. More specifically, experiments evaluate phytase based on either in vitro retention or in vivo measures, but rarely are both considered simultaneously. Therefore, six experiments were conducted at West Virginia University to elucidate variable effects in order to demonstrate how to properly assess the efficacy of microbial expressed phytase variants. The authors believe that several testing experiments are essential to properly assess phytase and sequence is important. The following variables were considered: 1) in vivo assays using lead candidates in mash feed; 2) optimization of enzyme production based on a specific expression host; 3) in vivo dosing assay using the best enzyme/host combination; 4) in vivo assay using incrementally increased pelleting temperatures. In vitro activity was determined for each experiment and in vitro retention using increasing pelleting temperatures was determined for experiments 1 and 2. All experiments utilized Cobb 500 broiler chickens and included a standard curve, generated by feeding incrementally increased non-phytate phosphorus (nPP) via inorganic phosphorus. Linear and quadratic regressions of the standard curve were tested to determine nPP sparing effects. Four experimental phytases were determined from in vitro activity; two of the four enzymes were chosen after the in vivo assay using mash feed. These two enzymes were expressed in yeast and bacterial hosts. The best enzyme/host combination was chosen for in vivo testing at various doses. Finally the enzyme/host combination at an appropriate dose was pelleted at incremental temperatures for in vivo testing. The best enzyme expressed in the yeast host at $750 \mathrm{FTU} / \mathrm{kg}$ was found to perform similar to a positive control diet. However, conditioning temperature during pelleting decreased performance compared to mash feed despite similar in vitro activity. 


\section{AKNOWLEDGEMENTS}

I would first like to thank my advisor and friend, Dr. Joseph Moritz for his guidance and support. I am deeply honored he has allowed me the opportunity to work within his lab. The people and connections I have been able to make will take my career to heights I never imagined, and for that I am eternally grateful. Next, I would like to thank my committee members, Dr. Janet Tou and Dr. Marlon Knights for their continued support throughout my research. I would also like to thank all WVU staff and faculty for all the help they have provided me. Research is a labor intensive job; therefore, I would like to extend my sincerest gratitude towards my fellow lab mates, both past and present, for all of their support and hard work throughout this journey: Kelley Wamsley, Kevin Shipe, Brittany Swiger, Laurel Shires, and Angela Lamp. Without their help, none of this would be possible. Lastly, I would like to thank my family: my parents Robbie and Sue, my grandmothers Mernie and Nina, my uncles Charles and Chester, and my boyfriend Willy. Without their support, patience, and constant motivation, I would have never made it to this precipice in my life. 


\section{TABLE OF CONTENTS}

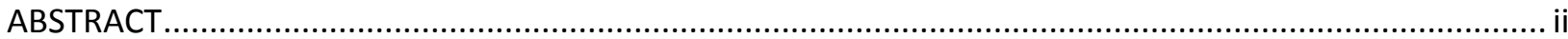

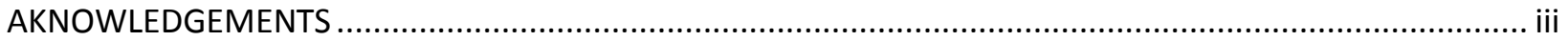

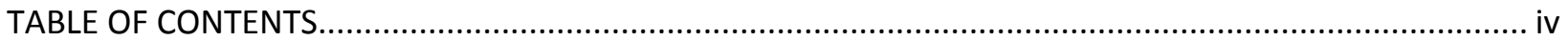

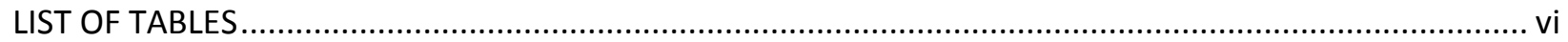

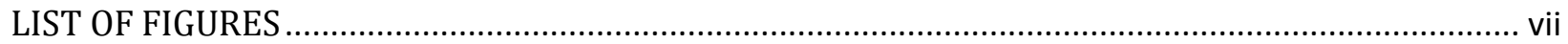

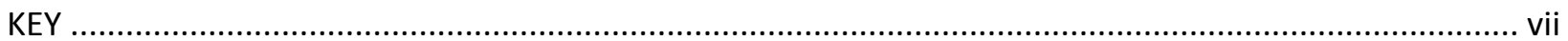

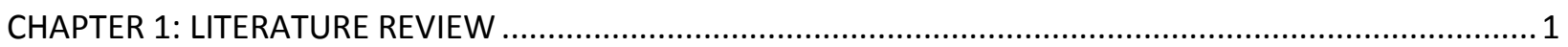

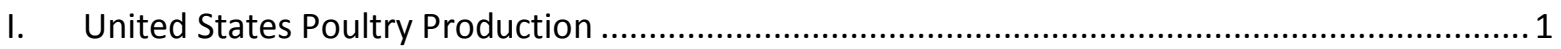

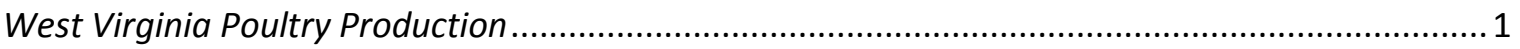

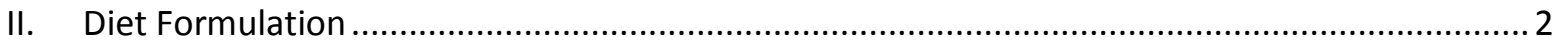

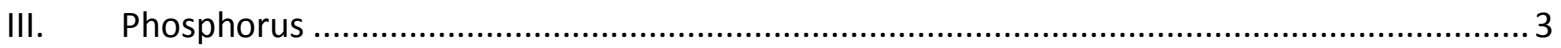

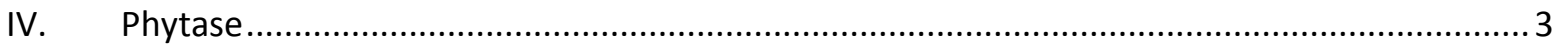

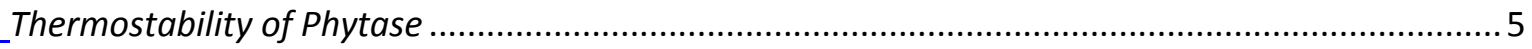

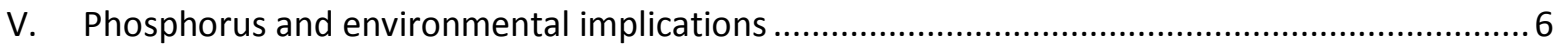

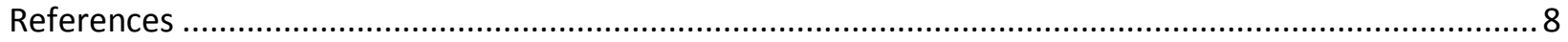

Chapter 2: Production and Evaluation of Novel Exogenous Phytase Enzymes ................................... 13

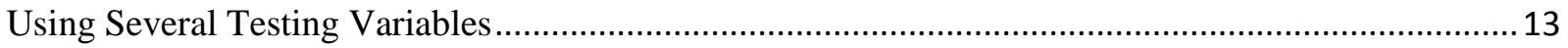

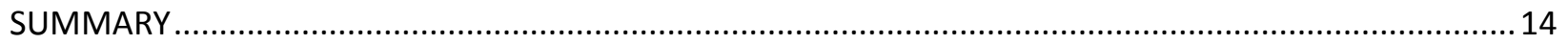

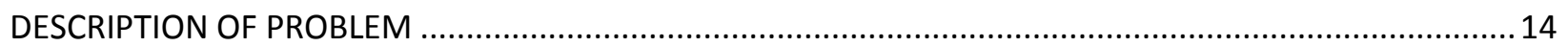

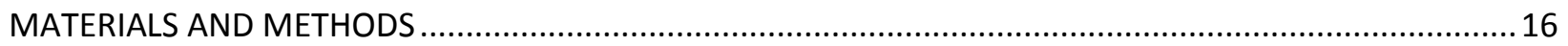

Experiment 1: in vivo assays using lead candidates in mash feed.................................................. 16

Experiment 2: Optimization of enzyme production based on a specific expression host......................20

Experiment 3: in vivo dosing assay using the best enzyme/host combination .................................... 21 
Experiment 4: in vivo assay using incrementally increased pelleting temperatures

Experiment 1: in vivo assays using lead candidates in mash feed

Experiment 2: Optimization of enzyme production based on a specific expression host.

Experiment 3: in vivo dosing assay using the best enzyme/host combination

Experiment 4: in vivo assay using incrementally increased pelleting temperatures............................26

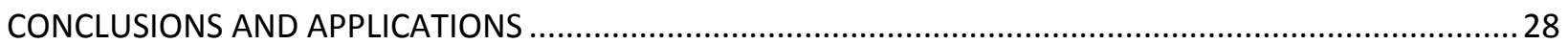

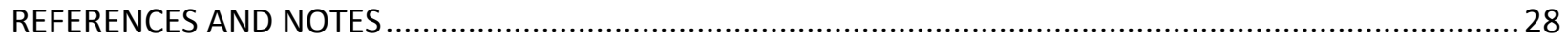

Table 1. Diet formulations for positive and negative control diets ...................................................... 32

Table 2. Phytase activity for Experiments 1, 2, $3^{1}$ using the AOAC 2000.12 method

Table 3. Phytase activity ${ }^{1}$ and retention for Experiment 4: in vivo assay using increasing pelleting temperature.

Table 4. Experiment 1: The effect of four lead candidate phytase enzymes utilized in mash feed on live bird performance

Table 5. Experiment 1: in vivo assay utilizing mash feed. Sparing effects calculated from the standard quadratic regression using tricalcium phosphate.

Table 6. Experiment 2: The effect of optimized enzyme production based on specific expression host on live bird performance

Table 7. Experiment 2: Optimized phytase production based on specific expression host. Sparing effects calculated from the standard linear and quadratic regression using tricalcium phosphate.

Table 8. Experiment 3: The effect of enzyme dosing levels on the best phytase enzyme/host combination measured through live bird performance.

Table 9. Experiment 3: in vivo dosing assay using the best enzyme/host combination chosen from Experiment 3. Sparing Effects calculated from standard curve quadratic regression using tricalcium phosphate.

Table 10. Experiment 4: The effect of phytase enzymes in pelleted feed on live bird performance.

Table 11. Experiment 4: in vivo assay using increasing pelleting temperature. Sparing Effects calculated from standard curve quadratic regression using tricalcium phosphate. 
Figure 1 . In vitro phytase retention of pellets conditioned at $75,80,85,88,90,93^{\circ} \mathrm{C}$ containing enzymes A - D (utilized in Experiment 1) using the AOAC 2000.12 method.....

Figure 2. In vitro phytase retention of pellets conditioned at $75,80,85,88,90,93^{\circ} \mathrm{C}$ containing enzymes B, C, B1, C1 (utilized in Experiment 2) using the AOAC 2000.12 method.

\section{LIST OF TABLES}

Table 1. Diet formulations for positive and negative control diets

Table 2. Phytase activity for Experiments 1, 2, $3^{1}$ using the AOAC 2000.12 method.....

Table 3. Phytase activity ${ }^{1}$ and retention for Experiment 4: in vivo assay using increasing pelleting temperature.

Table 4. Experiment 1: The effect of four lead candidate phytase enzymes utilized in mash feed on live bird performance......

Table 5. Experiment 1: in vivo assay utilizing mash feed. Sparing effects calculated from the standard quadratic regression using tricalcium phosphate.

Table 6. Experiment 2: The effect of optimized enzyme production based on specific expression host on live bird performance

Table 7. Experiment 2: Optimized phytase production based on specific expression host. Sparing effects calculated from the standard linear and quadratic regression using tricalcium phosphate.

Table 8. Experiment 3: The effect of enzyme dosing levels on the best phytase enzyme/host combination measured through live bird performance.

Table 9. Experiment 3: in vivo dosing assay using the best enzyme/host combination chosen from Experiment 3. Sparing Effects calculated from standard curve quadratic regression using tricalcium phosphate.

Table 10. Experiment 4: The effect of phytase enzymes in pelleted feed on live bird performance.

Table 11. Experiment 4: in vivo assay using increasing pelleting temperature. Sparing Effects calculated from standard curve quadratic regression using tricalcium phosphate. 


\section{LIST OF FIGURES}

Figure 1 . In vitro phytase retention of pellets conditioned at $75,80,85,88,90,93^{\circ} \mathrm{C}$ containing enzymes

A - D (utilized in Experiment 1) using the AOAC 2000.12 method.

Figure 2. In vitro phytase retention of pellets conditioned at $75,80,85,88,90,93^{\circ} \mathrm{C}$ containing enzymes

B, C, B1, C1 (utilized in Experiment 2) using the AOAC 2000.12 method.

\section{KEY}

\section{Chapter 1}

1. Phosphorus $-\mathrm{P}$

2. Adenosine triphosphate - ATP

3. Deoxyribonucleic acid - DNA

4. Ribonucleic acid - RNA

5. Available phosphorus $-\mathrm{aP}$

6. Inositol hexakisphosophate - IP6

7. Non-phytate phosphorus - nPP

8. United States Environmental Protection Agency - USEPA

9. Total maximum daily load - TMDL

10. Concentrated animal feeding operation - CAFO

11. Best management practice - BMP

\section{Chapter 2}

1. Negative control - NC

2. Positive control - PC

3. Non-phytate phosphorus - nPP

4. Live weight gain - LWG

5. Feed conversion ratio $-\mathrm{FCR}$

6. Feed intake - FI

7. Tibia ash percent - TA\%

8. Tibia ash mg/chick - TA mg/chick 


\section{CHAPTER 1: LITERATURE REVIEW}

\section{United States Poultry Production}

The United States is the largest producer of poultry in the world and the second largest egg producer. In 2010, the value of production from all poultry products (broilers, eggs, turkeys, chickens) was $\$ 34,657,313$. From this, $\$ 23,696,132$ was specifically broiler production. These values are 10 percent higher as compared to 2009 , with $\$ 31,627,349$ for total production and $\$ 23,696,132$ for broilers [1].

The United States commercial poultry industry is vertically integrated, allowing for product quality control throughout an entire grow-out and processing period. The integrator will own the feed mill, hatchery, breeder flock, and processing plant(s) in a particular area. They are responsible for supplying the grower with the chicks, feed, supervision, the transportation of both the chicks and feed, and the processing of the final product. The grower will be under a contract with the integrator and will be responsible for daily labor (management, etc.), facilities (house, etc.), and any energy costs (electric, gas). At the end of a grow-out, typically 38 to 42 days, the birds are caught and loaded onto trucks, hauled to a processing plant and weighed. The grower is paid by pound of live weight (approximately $\$ 0.05 / \mathrm{lb}$.) and due to the short grow-out period (approximately 6 weeks), can have up to seven flocks of birds per year.

\section{West Virginia Poultry Production}

Poultry is West Virginia's number one agricultural commodity. In fact, the state is ranked $15^{\text {th }}$ in the country for broiler production. From December 1, 2009 to November 30, 2010, 87.6 million broilers were produced in West Virginia. This resulted in 346 million pounds 
of chicken, valued at $\$ 167$ million [1]. The majority of this poultry is raised in five counties located in the Eastern Panhandle: Hardy, Grant, Hampshire, Mineral, and Pendleton. Most of this product is processed in Moorefield, WV, where 2 million birds are processed each week. Pilgrim's Pride is the main integrator in West Virginia and is the largest producer in the country.

\section{Diet Formulation}

Feed and feed manufacture comprise approximately $70-75 \%$ of total production cost and diet formulation is one of the most important factors affecting this cost, and subsequently bird performance. Most nutritionists formulate diets to be least cost while still fulfilling the animal's nutritional requirements. To formulate diets, the use of by-products is necessary; however, these by-products can affect pellet quality. Pellet quality is defined as the ability of a feed pellet to maintain its structural integrity from the feed mill to the feed pan [2]. Several techniques can be employed to increase pellet quality. Increasing conditioning temperature increases moisture and heat within the feed, thus improving pellet quality [3].

Recently corn prices in the United States have risen drastically primarily due to ethanol production. Fat prices have also begun to increase. Current industry practice is to use a low inclusion of fat to keep diet costs low and apply as little fat as possible at the mixer to improve pellet quality [4]. However, research has shown that low mixer-added fat can be harmful to certain heat sensitive nutrients and mixer-added exogenous enzymes $[4,5,6]$. High mixer-added fat inclusion has shown to improve enzyme efficacy by coating the feed particles [7] and providing lubrication within the die to decrease frictional heat [8]. 


\section{Phosphorus}

Phosphorus (P) is a mineral nutrient required by all life forms. It plays a critical role in cellular metabolism, part of the energy currency of cells, cellular regulatory mechanisms, and in bone [9]. $\mathrm{P}$ is a component of adenosine triphosphate (ATP), deoxyribonucleic acid (DNA), ribonucleic acid (RNA), and phospholipids found in cell membranes. Bone is the largest storage form of $\mathrm{P}$, accounting for $85 \%$ of the body's total $\mathrm{P}$ [9]. It is especially important to broiler chicks that grow from 50 grams to approximately $2.5 \mathrm{~kg}$ in only 42 days. Therefore, it is vital that broilers have strong skeletal systems to support their large body mass and meat production.

Phosphorus can be obtained from several sources in a diet. Some ingredients (i.e. corn and soybean) contain minute amounts of $\mathrm{P}$ and approximately $2 / 3$ of this $\mathrm{P}$ is in the phytate form, making it unavailable for non-ruminants [10]. The largest quantity of available phosphorus (aP) is obtained from inorganic feed phosphates, derived from rock phosphates. While these sources supply the animal with aP, they are expensive and non-renewable [11]. There are various names for both phytate and non-phytate phosphorus and depends on what form the molecule is found in. Phytic acid or inositol hexakisphosphate (IP6) is a phosphorylated cyclic sugar alcohol. In salt or anion form, it is referred to as phytate. In mature seeds, phytate is present as a complex salt of calcium, magnesium, and potassium, and can sometimes also be bound to proteins and starches. This chelated molecule is known as phytin and is commonly referred to as non-phytate phosphorus (nPP) [12].

\section{Phytase}

Phytases are phosphatase enzymes able to catalyze the hydrolysis of phosphate ester bonds. Phytases are most commonly found in plants and can be produced by various bacteria, 
including micro flora found in the GI tract [13]. However, poultry and other monogastrics produce minimal endogenous phytase [14]. Therefore, since the early 1990's the commercial poultry industry has been incorporating exogenous phytase to feed in order to significantly increase phosphorus availability and utilization $[15,16]$, as well as decrease environmental impact [17]. Phytase enzymes can be expressed from different types of organisms and the host organism can dramatically affect how the enzyme performs in vivo. The first commercially available phytase, developed in the 1990's, was derived from Aspergillus niger. Currently, phytase products include those expressed from a variety of fungal, bacterial, yeast, and plant sources [18]. Cultures of Escherichia coli are often used to produce phytase because it can produce the enzyme quickly and in high volume compared to other sources [19].

Two classes of phytase enzymes exist; 1) a 3-phytase; and 2) a 6-phytase which cause dephosphorylation of the IP6 molecule at either the 3 or 6 position on the inositol ring, respectively. Generally, plants produce 6-phytase and microorganisms produce 3-phytase [20, 21]; however, researchers have reported 6-phytase activity in Escherichia coli [22] and 3-phytase activity in soybeans [23]. In vitro and in vivo studies have demonstrated differences in biochemical properties and efficacy between phytase sources [24, 25]. This may be related to their optimum $\mathrm{pH}$ and stereospecificity of phytate hydrolysis (3- or 6-phytase). The pH optimum for phytase activity for $A$. niger is bimodal ( $\mathrm{pH} 2.5$ and 5.5), whereas it occurs at $\mathrm{pH} 4.0$ to 4.5 for Peniophora lycii and $\mathrm{pH} 2.5$ to 3.5 for E. coli derived phytase [26]. A. niger phytase is a 3phytase, whereas P. lycii and E. coli-derived phytases are 6-phytases [27, 28].

The host organism also affects the site of phytase activity; it is likely that phytate hydrolysis takes place in the fore-stomach of poultry i.e. crop, proventriculus, and gizzard. The crop is most likely the primary site of phytate degradation by exogenous phytase $[29,30,31]$. 
However, there is evidence to suggest that $E$. coli-derived phytases are more active in the small intestine than phytases derived from $P$. lycii [32]. This may be attributed to the greater resistance of E. coli-derived phytases to endogenous, proteolytic enzymes [33].

\section{Thermostability of Phytase}

The structure of phytase is important to its function; it can be altered by heat, $\mathrm{pH}$, and some organic solvents which can decrease or deplete an enzyme's activity [34]. Most poultry feed in the United States is pelleted, requiring it to be subjected to increased pressure, moisture, and temperature. A study conducted by Kirkpinar and others demonstrated denaturation of phytase preparations after steam conditioning at $60^{\circ} \mathrm{C}$ [35] while Hughes reported decreased phytase activity at $75^{\circ} \mathrm{C}[36]$.

Phytase enzymes have an optimal temperature range from $45-77^{\circ} \mathrm{C}$, depending upon source. A phytase originating from Aspergillius niger is described as having activity at temperatures between $25-65^{\circ} \mathrm{C}$, with $55^{\circ} \mathrm{C}$ being the optimum [37]. Wyss and others studied the denaturation of two phytase isolates, one derived from A. fumigatus and one derived from $A$. niger; both enzymes were found to denature at $55^{\circ} \mathrm{C}$. An interesting result seen was after submitting the isolates to a temperature of $90^{\circ} \mathrm{C}$, the phytase derived from A. fumigatus refolded into its active conformation while the phytase derived from A. niger did not [38]. Other research demonstrated that steam conditioning feed at temperatures of $78-81^{\circ} \mathrm{C}$ did not lower enzyme activity, but enzyme activity decreased at $84-87^{\circ} \mathrm{C}$ [39]. Gibson showed that two of three phytase preparations suffered inactivation after being exposed to temperatures of $65-95^{\circ} \mathrm{C}$; however, only one commercially available enzyme retained the majority of its activity when pelleted at $85^{\circ} \mathrm{C}$ and above [40]. Pasamontes and coauthors reported a heat-stable phytase able 
to withstand pelleting temperatures up to $100^{\circ} \mathrm{C}$ over a period of 20 minutes, with a loss of only $10 \%$ of the initial enzyme activity [41].

Most past research has viewed in vitro and in vivo phytase efficacy as separate experiments. This demonstrates great inconsistency among phytase enzymes. Most of the aforementioned research only looked at heat stability in vitro, while more recent research has shown that high enzyme efficacy in vitro does not necessarily correlate to bird performance [42]. One study reported improved FCR and tibia ash percentage by phytase supplementation; however, in vitro enzyme activity was not considered [43]. Pasamontes and others reported a heat-stable phytase that could withstand pelleting temperatures of $100^{\circ} \mathrm{C}$, however, the authors did not measure subsequent bird performance [41].

\section{Phosphorus and environmental implications}

Another reason the poultry industry has embraced phytase enzymes is due to environmental regulations; one such local example is the Chesapeake Bay Watershed, consisting of 64,000 square miles in parts of six different states: New York, Pennsylvania, Virginia, Maryland, West Virginia, and Delaware [44]. Over the past several years, nutrients such as nitrogen and phosphorus have accumulated in the Chesapeake Bay; these nutrients come from many sources, however, agricultural practices have been pinpointed as the main cause of pollution, specifically

poultry. Over-enrichment of a body of water caused by these nutrients can lead to eutrophication which is defined as the accumulation of organic matter [45]. Eutrophication can lead to algal blooms and the depletion of available oxygen levels in the water. This process results in an unbalanced system resulting in the death of many organisms, including fish and plant life. Eutrophication has been identified as the main problem of surface waters [46]. With the increase 
in both the concentration of poultry production and operation size in many regions of the United States, has led to an increase in manure application to the land. This application of manure has resulted in more $\mathrm{P}$ being added than crops require, an accumulation of $\mathrm{P}$, and an increased potential in $\mathrm{P}$ surface runoff [47]. $\mathrm{P}$ inputs in a body of water can increase the potential for eutrophication $[48,49]$.

To combat the over-enrichment of the Chesapeake Bay, the United States Environmental Protection Agency (USEPA) has established Total Maximum Daily Load (TMDL) for waterways, setting maximum limits of nitrogen and phosphorus that the body of water can receive. For the Chesapeake Bay to meet the requirements set in the Clean Water Act, the TMDL limits the amount of $\mathrm{P}$ influx to 12.5 million lbs per year. This would eventually result in a $24 \%$ reduction of $\mathrm{P}$ in the bay, thus decreasing eutrophication [50].

Due to agriculture operations being pinpointed as the main pollution source, the USEPA has also defined a concentrated animal feeding operation or CAFO. The definition of a CAFO is any feeding operation that confines a set number of animals for 45 days or more in a 12 month period. A poultry facility is considered a CAFO if it confines 30,000 or more broiler or at least 55,000 turkeys [51]. If a facility is determined to be a CAFO, a voluntary or incentive-based best management practice (BMP) may be implemented. BMPs consist of three parts; 1) soil information for a particular area is collected; 2) the crop potential and amount of nutrients required to reach that potential is determined; 3) manure application rate is recommended for the area or field [52]. BMPs are devised to help reduce eutrophication in the Chesapeake Bay.

Adding phytases to poultry diets has shown many positive effects including: decreasing diet costs, increasing performance, and decreasing environmental impact. However, many 
researchers do not consider in vitro and in vivo experiments combined to obtain data that accurately assess exogenous enzyme potential.

\section{References}

1) USDA. Poultry Production and Value. http://usda.mannlib.cornell.edu/usda/current/PoulProdVa/PoulProdVa-04-28-2011.pdf. Accessed October 3, 2011.

2) Cramer, K. R., K. J. Wilson, J. S. Moritz, and R. S. Beyer. 2003. Effect of sorghum-based diets subjected to various manufacturing procedures on broiler performance. J. Appl. Poult. Res. 12:404-410.

3) Fairchild, D. A. 2003. Pelleting for profit. National Grain and Feed Association. Feed and Feeidng Digest. Vol. 54. N. 6.

4) Gehring, C.K. 2009.Improvement of the physical and nutritional quality of pelleted feed. M.S. Thesis. West Virginia University, Morgantown.

5) N.P. Buchanan, K.G.S. Lilly, C.K. Gehring, and J.S. Moritz. The effects of altering diet formulation and manufacturing technique on pellet quality. J. Appl. Poult. Res. 2010 19:112-120.

6) Lilly, K. G. S., C. K. Gehring, K. R. Beaman, P. J. Turk, M. Sperow, and J. S. Moritz. 2011. Examining the relationships between pellet quality, broiler performance, and bird sex. J. Appl. Poult. Res. 20: 231 - 239.

7) Zimonja, O., A. Stevnebø, and B. Svihus. 2007. Nutritional value of diets for broiler chickens as affected by fat source, amylose level and diet processing. Can. J. Anim. Sci. 87:553-562.

8) Cutlip, S.E., J.M. Hott, N.P. Buchanan, A.L. Rack, J.D. Latshaw and J.S. Moritz. 2008. The effect of steam conditioning practices on pellet quality and growing broiler nutritional value. J. Appl. Poult. Res. 17:241-269.

9) Applegate, T. J., and R. Angel. 2008. Animal sciences: phosphorus requirements for poultry. Purdue University Cooperative Extension Service, West Lafayette, IN.

10) Angel, R. 2011. Calcium and Phosphorus Requirements in Broilers and Laying Hens. Australian Poultry Science Symposium, Sydney, New South Wales. Poultry Research Foundation, University of Sydney and World's Poultry Science Association, Australia. 
11) Grimbergen, A. H. m., J. P. Cornelissen, and H. P. Stappers. 1985. The relative availability of phosphorus in inorganic feed phosphates for young turkeys and pigs. Anim. Feed Sci. and Technol. 13: 117 - 130.

12) Graf, E. 1986. Chemistry and applications of phytic acid: anoverview. Phytic Acid: Chemistry and Applications, E. Graf, ed. Pilatus Press, Minneapolis, MN. 173-194.

13) Angel, R., N. M. Tamim, T. J. Applegate, A. S. Dhandu, and L. E. Ellestad. 2002. Phytic acid chemistry: influence on phytin-phosphorus availability and phytase efficacy. J. Appl. Poult. Res. 11:471-480.

14) Nelson, T. S. 1976. The hydrolysis of phytin phosphorus by chicks and laying hens. Poult. Sci. 55:2262-2264.

15) Ravindran, V., W. L. Bryden, and E. T. Kornegay. 1995. Phytin: Occurrence, bioavailability and implications in poultry nutrition. Poult. Avian Biol. Rev. 6:125-143.

16) Shaw, A.L., Blake, J.P., and Gordan, J.W. 2010. Evaluation of commercial phytase enzymes on performance and tibia-breaking strength of male broiler chicks. J. Appl. Poult. Res. 19:415-421.

17) Mullaney, E. J., C. B. Daly, and A. H. J. Ullah. Advances in Phytase Research. Adv. Appl. Microbio. 47: 157 - 199.

18) Wodzinski, R. J., and A. H. J. Ullah. 1996. Phytase. Adv . Appl. Microbiol. 42: 263 302.

19) Viveros, A., C. Centeno, A. Brenes, R. Canales, and A. Lozano. 2000. Phytase and acid phosphatase activities in plant feedstuffs. J. Agric. Food Chem. 48:4009-4013.

20) Reddy, N. R., S. K. Sathe, and D. K. Saunkhe. 1982. Phytates in legumes and cereals. Adv. Food Res. 28:1-92.

21) Nayini, N. R., and P. Markakis. 1986. Phytases. Phytic Acid: Chemistry and Applications. E. Graf, ed. Pilatus Press, Minneapolis, MN. 101-118.

22) Greiner, R., U. Konietzny, and K. D. Jany 1993. Purification and characterization of two phytases from Escherichia coli. Arch. Biochem. Biophys. 303:107-113.

23) Phillippy, B. Q., M. R. Johnston, S. H. Tao, and M. R. S. Fox. 1988. Inositol phosphates in processed foods. J. Food Sci. 53:496-499.

24) Rodriguez, E., Y. M. Han, and X. G. Lei. 1999. Cloning, sequencing, and expresson of an Escherichia cloi acid phosphatase/phytase gene (appA2) isolated from pig colon. Biochem. Biophys. Res. Comm. 257: 117 - 123. 
25) Yin, Q. Q., Q. H. Zheng, and X. T. Kang. 2007. Biochemical characteristics of phytases from fungi and the transformed microorganism. Anim, Feed Sci. Technol. 132: $341-$ 350.

26) Adeola, O., J. S. Sands, P. H. Simmins, and H. Schulze. 2004. The efficacy of an Escherichia coli-derived phytase preparation. J. Anim. Sci. 82: 2657 - 2666.

27) Kornegay, E. T. 2001. Digestion of phosphorus and oter nutrients: The role of phytases and factors influencing their activity. Pages 237 - 272 in Enzymes in Farm Animal Nutrition. M. R. Bedford and G. G. Partridge, eds. CAB International, Wallingford, UK.

28) Augspurger, N. R., D. M. Webel, X. G. Lei, and D. H. Baker. 2003. Efficacy of and E. coli phytase expressed in yeast for releasing phytate-bound phosphorus in young chicks and pigs. J. Anim. Sci. 81: $474-483$.

29) Leibert, F., C. Wecke, and F. J. Schoner. 1993. Phytase activities in different gut contents of chickens as dependent on level of phosphorus and phytase supplementations. Int Proceedings of $1^{\text {st }}$ European Symposium Enzymes in Animal Nutrition, pp. $202-205$.

30) Takemasa, M., H. Murakami, and M. Yamazaki. 1996. Reduction of phosphorus excretion of chicks by addition of yeast phytase. Jpn. Poult. Sci. 33: $104-111$.

31) Kerr, M. J., H. L. Classen, and R. W. Newkirk. 2000. The effects of gastrointestinal traft micro-flora and dietary phytase on inositol hexaphosphate hydrolysis in the chicken. Poult. Sci. 79 (suppl. 1), 11 (abstract).

32) Onyango, E. M., M. R. Bedford, and O. Adeola. 2005. Phytase activity along the digestive tract of the broiler chick: a comparative study of an Escherichia coli-derived and Peniophora lycii phytase. Can. J. Anim. Sci. 85: 61 - 68.

33) Igbasan, F. A., O. Simon, G. Milksch, and K. Manner. 2000. Comparative studies of the in vitro properties of phytases from various microbial origins. Ach. Anim. Nutr. 53: $353-$ 373.

34) Spring, R. J., and A. H. J. Ullah. 1996. Phytase. Advances in Applied Microbiology. 42: 263-302.

35) Kirkpinar, F., H. Basmacioglu. 2006. Effects of pelleting temperature of phytase supplemented broiler feed on tibia mineralization, calcium, and phosphorus content of serum and performance. Czech Journal of Animal Science. 51: 78-84.

36) Hughes, A., 1993. Importance of phytates and cereal phytases in the feeding of pigs. Enzymes in Animal Nutrition. C Wenk, ed. ETH-Zurich, Zurich. pp. 192 -198. 
37) Pandey, A., G. Szakacs, C. R. Soccol, J. A. Rodriguez-Leon, and V. T. Soccol. 2001. Production, purification, and properties of microbial phytases. Biores. Technol. 77: 203 214.

38) Wyss, M., Pasamontes,L., Remy,R., Kohler, J., Kusznir, E., Gadient, M., Muller,F., and VanLoon, A.P.G.M. (1998) Comparision of the thermostability properties of three acid phosphatases from molds: Aspergillus fumigates phytase, A. niger phytase, and A. niger pH 2.5 acid phosphatase . Applied and Environmental Microbiology 64: 4446-4451.

39) Simons, P.C.M., Versteegh, H.A.J., Jongbloed, A.W., Kemme, P.A., Slimp,P., Bos, K.D., Wolters, M.G.E., Beudeker, R.F., and Verschoor, G.J. (1990) Improvement of phosphrous availability by microbial phytase in broilers and pigs. British Journal of Nutrition. 64: 525-540.

40) Gibson, K. (1995) The pelleting stability of animal feed enzymes. In: van Hartingsveldt, W., Hessing, M., van der Lugt,J.T. and Somers.W.A.C. (eds) Proceedings of the $2^{\text {nd }}$ Annual Symposium on enzymes in animal nutrition. Noordwijkerhout, The Netherlands, pp 157-162.

41) Pasamontes, L., M. Haiker, M. Wyss, M. Tessier, and A. P. G. M. vanLoon. 1997. Gene cloning, purification, and characterization of a heat-stable phytase from the fungus Aspergillus fumigatus. Appl. Enivon. Microbio. 63: 1696 - 1700.

42) Loop, S. A., K. G. S. Lilly, L. K. Shires, C. K. Gehring, K. R. Beaman, M. E. Persia, and J. S. Moritz. Phytase analytical activity of pelleted diets may not adequately describe efficacy in the bird. J. Appl. Poult. Res. (In press).

43) Timmons, J. R., R. Angel, J. M. Harter-Dennis, W. W. Saylor, and N. E. Ward. 2008. Evaluation of heat-stable phytases in pelleted diets fed to broilers from day zero to thirtyfive during the summer months. J. Appl. Poult. Res. 17: $482-489$.

44) Chesapeake Bay Watershed. http://chesapeakebay.net/. Accessed February 29, 2012.

45) Rabalias, N.N., Turner, R.E., Diaz, R. J., and Justic, D. Global change and Eutrophication of coastal water. Ices Journal of Marine Science. 66: 1528-1537.

46) United States Environmental Protection Agency. 1996. Environmental indicators of water quality in the United States. EPA 841-R-96-002. USEPA, Office of Water, U.S. Government Printing Office, Washington, DC.

47) Sharpley, A. 1999. Agricultural phosphorus, water quality, and poultry production: Are they compatible?. Poult. Sci. 78:660-673. 
48) Schindler, D. W., 1977. Evolution of phosphorus limitation in lakes. Science 195: 260 262.

49) Carpenter, S. R., N. F. Caraco, D. L. Correll, R. W. Howarth, A. N. Sharpley, and V. H. Smith. 1998. Nonpoint Pollution of surface waters with phosphorus and nitrogen. Ecol. Appl. 8:559-568.

50) United States Environmental Protection Agency. 2011. Chesapeake Bay TMDL. http://www.epa.gov/reg3wapd/tmdl/ChesapeakeBay/index.html. asp Accessed January 10, 2012.

51) United States Environmental Protection Agency. Federal Register. http://www.epa.gov/npdes/regulations/cafo_final_rule_preamble2008.pdf. Accessed March 6, 2012.

52) United States Environmental Protection Agency. Best Management Practices. http://www.epa.gov/agriculture/anafobmp.html. Accessed March 6, 2012. 
Chapter 2: Production and Evaluation of Novel Exogenous Phytase Enzymes Using Several Testing Variables

A. M. Evans ${ }^{1}$, K. G. S. Wamsley, K. J. Shipe, A. E. Lamp, and J. S. Moritz Division of Animal and Nutritional Sciences, West Virginia University, Morgantown, West Virginia, 26506-6108

Phone: 304-293-1911

Fax: 304-293-2232 


\section{SUMMARY}

Most commercial broilers are fed pelleted diets containing exogenous phytase. This enzyme is used to decrease diet costs, increase performance, and reduce environmental impact. Technology exists to prevent denaturation of phytase during pelleting, however, the potential remains for the enzyme to lose efficacy in liberating phytate bound phosphorus. Combining this technology with proper testing methodologies creates superior phytase molecules for further field testing. Several testing experiments are essential to properly assess exogenous phytases and their sequence is important: : 1) in vivo assay using lead candidates in mash feed; 2) optimization of enzyme production based on a specific expression host; 3 ) in vivo dosing assay using the best enzyme/host combination; 4) in vivo assay using incrementally increased pelleting temperatures. In vitro activity was determined for each experiment Four candidates (A -D) were chosen for testing in experiment 1 . An optimal expression host was then determined (B1). Dosing demonstrated that B1 performed best at 1,000 FTU/kg, with no statistical difference between positive control or 750 FTU/kg. The 750 FTU/kg does was chosen to determine pelleting retention due to potential for increased sensitivity. Pelleting decreased performance when compared to mash with enzyme activity at similar levels. Pelleting at $75^{\circ} \mathrm{C}$ demonstrated nPP sparing $0.05-0.16 \%$ and decreased as conditioning temperature increased. Further production modifications are necessary to maximize this enzymes thermal stability prior to field testing.

\section{DESCRIPTION OF PROBLEM}

Most commercially raised broilers consume a corn-soybean based diet. The majority of the phosphorus in these grains is in the form of phytate bound phosphorus, which is unavailable 
to the bird. Phytase enzymes can be incorporated into diets in order to hydrolyze phytate bound phosphorus into bioavailable phosphorus that can be utilized by the bird.

Commercially reared broilers are exclusively fed pelleted diets and the benefits of pelleting have been reported by multiple studies and include: increased intake [1], productive energy [2], and feed flow [1], as well as decreased feed wastage and ingredient segregation [2]. Pelleting requires feed to be exposed to conditions of high temperature, pressure, and moisture. These factors increase pellet quality by starch gelatinization $[3,4,5]$ and protein denaturation and gelation $[6,7]$. Liquid phytases can be added post-pellet; however, this type of application has been associated with decreased pellet quality due to the blend lines associated with application [8]. Furthermore, if liquid application provides phytase in only the outer layers of the pellet, then attrition associated with feed conveyance may reduce uniformity of phytase delivered throughout a poultry barn. Mixer-added phytases alleviate the issues associated with liquid phytases; however, thermostability becomes a concern, because phytases are proteins and proteins can denature during pelleting. Therefore, phytase enzymes added at the mixer must be able to withstand conditions associated with the pelleting process.

Multiple studies have shown that phytase enzymes lose activity at temperatures as low as $60^{\circ} \mathrm{C}[9,10]$ as determined using mild pelleting conditions and in vitro analysis. However, there are no standard conditions in feed manufacture. Variations in equipment, ingredients, ambient temperature, and manufacturing goals among commercial feed mills require more versatility from a mixer-added phytase. Therefore, biotechnology companies have attempted to produce phytases that are naturally heat stable and/or genetically modified to improve thermal stability [11]. It is important to determine phytase retained activity under the conditions of pelleting 
because these diets are fed to commercial broilers and if the enzyme cannot survive the pelleting process, then nutritional and environmental benefits cannot be realized.

The objective of the current study was to utilize several experiments in order to properly assess the efficacy of microbial expressed phytase variants to be added at the mixer using an all variable inclusive approach.

\section{MATERIALS AND METHODS}

\section{Experiment 1: in vivo assays using lead candidates in mash feed}

in vivo assay - diet preparation

Four enzyme variants (A, B, C, D), expressed in a yeast host were mixed into mash diets to test their efficacy in vivo. In addition, diets without phytase containing incrementally increasing amounts of inorganic phosphorus were used to provide standards for comparison. These standard diets consisted of a negative control (NC) formulated for $0.25 \%$ non-phytate phosphorus (nPP), a positive control (PC) formulated for $0.45 \% \mathrm{nPP}$, a 3:1 ratio of PC: $\mathrm{NC}$, and a 1:3 ratio of PC:NC (Table 1). The standard diets were included so that $\mathrm{P}$ sparing of the phytases could be determined. The 4 different enzyme variants were added to separate NC diets, creating 4 dietary treatments $(\mathrm{NC}+\mathrm{A}, \mathrm{NC}+\mathrm{B}, \mathrm{NC}+\mathrm{C}, \mathrm{NC}+\mathrm{D}) . \quad$ Dietary $\mathrm{nPP}$ levels were calculated using ingredient estimates of $\mathrm{P}$ availability. Diet formulations for PC and NC were kept as similar as possible with respect to ingredient inclusion (Table 1). In addition, values for ME, TSAA, lysine, and calcium were held constant. Soybean oil was included at $3 \%$ and added at the mixer to aid in enzyme retained activity [12]. The primary difference between PC and NC was nPP level (0.45 and $0.25 \%$, respectively; Table 1$)$. 
All feed was manufactured at West Virginia University's pilot feed mill. A $930 \mathrm{~kg}$ allotment of feed was batched in accordance to the NC. An additional $386 \mathrm{~kg}$ allotment of feed was batched in accordance to the PC. All batches were mixed for ten minutes with dry ingredients, and an additional ten minutes post soybean oil addition using a single screw vertical mixer [13]. Both NC and PC batches were divided into $136 \mathrm{~kg}$ allotments. Appropriate exogenous enzyme variants were introduced into $4.5 \mathrm{~kg}$ of mash at a concentration to provide 500 FTU/kg (a common commercial phytase inclusion $[16,17])$ and mixed for 10 minutes using a small paddle mixer [14]. The small batch was then introduced back to the designated $136 \mathrm{~kg}$ batch and mixed an additional ten minutes [13]. A 300 gram sample was analyzed for crude protein, calcium, total $\mathrm{P}$, phytic acid, and phytase activity at a commercial laboratory [15]. The $\mathrm{nPP}$ values were calculated for all diets using the following equation: total $\mathrm{P}$ of feed $-(0.282 \mathrm{X}$ phytic acid of feed) [18].

In vitro activity and retention were determined using the Association of Official Agricultural Chemists (AOAC) 2000.12 method. This procedure is a colorimetric enzymatic method that is widely applied to commercially available and experimental phytases. The principle of this method is to incubate a sample containing phytase with sodium phytate at $37^{\circ} \mathrm{C}$ and $\mathrm{pH}$ 5.5. This step liberates inorganic phosphate. Incubation is stopped by adding acid molybdate-vanadate reagent, which produces a yellow color (yellow vanadomolybdophosphor complex), an indicator of liberated phosphate [19]. The enzyme activity is expressed in activity units (FTU), where one FTU is equivalent to the amount of enzyme that liberates $1 \mu \mathrm{mol}$ of inorganic orthophosphate/min from 0.005 moles of sodium phytate/L at $\mathrm{pH} 5.5$ and $37^{\circ} \mathrm{C}[20]$. 


\section{Live Bird Performance}

A total of 540 1-d old male Cobb 500 [21] broiler chicks were obtained from a commercial hatchery [22]. For the first three days of life chicks were fed the NC diet as a pretest in a floor pen setting. On d 3, all chicks were individually weighed and allotted into 8 weigh groups. One bird from each group was placed in each 64 raised wire battery cages to create the experimental unit. Each of the dietary treatments were randomly assigned to pens blocked by location, creating a randomized complete block design. Feed and water were provided for ad libitum consumption. Measured variables for the $\mathrm{d} 3-21$ experimental period included: feed intake (FI), live weight gain (LWG), and feed conversion ratio (FCR), corrected for mortality weight. On d 21, birds were weighed by pen and killed via cervical dislocation and the left tibiae were extracted in order to determine bone mineralization.

\section{in vitro retention assay - diet preparation}

As stated previously, mixer-added phytase enzymes must be heat stable to survive the pelleting process; therefore, in vitro activity was determined for enzymes of Experiment 1 before and after pelleting. All feed was manufactured at West Virginia University's pilot feed mill. Three 725.9 $\mathrm{kg}$ allotments of the NC diet (Table 1) were mixed for ten minutes dry, and an additional ten minutes post soybean oil addition using a single screw vertical mixer [13]. Each NC batch of $725.9 \mathrm{~kg}$ was then split into four allotments. Allotments from each batch were combined to create nutritionally uniform diets to be pelleted. Prior to pelleting, $4.5 \mathrm{~kg}$ of mash were premixed with the appropriate exogenous enzyme variant at a concentration such that would provide $500 \mathrm{FTU} / \mathrm{kg}$ and mixed for 10 minutes in a small paddle mixer. The $4.5 \mathrm{~kg}$ allotment was then placed back into the designated batch and mixed an additional twenty minutes prior to 
pelleting. All treatments were passed through a $1.3 \mathrm{~m}(4.26 \mathrm{ft})$ long conditioner with a diameter of $0.31 \mathrm{~m}(1.02 \mathrm{ft})$ and $10 \mathrm{sec}$ retention time [23]. Treatments were steam conditioned in a sequential manner, ie. $75,80,85,88,90,93^{\circ} \mathrm{C}$. Pellets were formed using a 40-horsepower California Pellet Mill [24] equipped with a 38mm x 4.8mm (1.49 x 0.19in) pellet die. The pellets were cooled with ambient air utilizing a horizontal belt cooler [25]. Once conditioning temperature reached a steady state during pelleting, mash samples were taken from the feed screw auger that conveyed feed into the conditioner and corresponding pellet samples were taken from the cooler discharge. These samples were then analyzed for crude protein, calcium, total P, phytic acid, and phytase activity at a commercial laboratory [12].

\section{Statistical analysis}

Data was analyzed using one-way analysis of variance (ANOVA) using SAS software [26]. Significant differences were determined based on $\alpha \leq 0.05$. Means were separated using Fisher's least significant difference test and letter superscripts were used to denote differences among treatment means. Variables measured included: LWG, FI, FCR, mortality percentage, $\mathrm{TA} \%$, and TA mg/chick. Linear and quadratic regressions were performed on standard diets, to determine the $\mathrm{P}$ sparing of the phytases, if the ANOVA indicated significant differences. Linear regression was determined by plotting the means of the standard diets and using the equation:

$$
\mathrm{y}=\mathrm{m}(\mathrm{x})+\mathrm{b}
$$

The y-term is the mean of the enzyme treatment, the m-term is the slope of the line, the $\mathrm{x}$-term is the variable being calculated, and the b-term is the y-intercept of the line. When $\mathrm{x}$ is determined, the nPP value of the NC can be subtracted to provide and indication of the amount of nPP spared by use of the enzyme treatment. 
Quadratic regression was determined by using the equation:

$$
y=a\left(x^{2}\right)+b(x)+c .
$$

The equation is set equal to zero, and is solved for $\mathrm{x}$. By doing this, the equation becomes:

$$
x=\frac{-b \pm \sqrt{b^{2}-4 a c}}{2 a}
$$

When the equation is solved, two values of $\mathrm{x}$ emerge. To determine the appropriate $\mathrm{x}$ value for further calculations, the vertex of the curve was calculated and the $\mathrm{x}$ lying to the left of the vertex was selected. This $\mathrm{x}$ value should lie within the range of nPP evaluated with the standard diets, making it most relevant. The $\mathrm{P}$ sparing was calculated similar to the linear regression, where the nPP value of the $\mathrm{NC}$ is subtracted from the $\mathrm{x}$ value. The linear regression $\mathrm{P}$ sparing was only included if the quadratic regression was not found to be significant.

\section{Experiment 2: Optimization of enzyme production based on a specific expression host}

Successful candidates from Experiment 1, defined by superior performance and tibia measures, (enzymes B and C) were selected for testing in a bacterial expression host. These treatments were defined as $\mathrm{NC}+\mathrm{B} 1$ and $\mathrm{NC}+\mathrm{C} 1$. In addition, these same enzymes expressed in yeast were again evaluated (B and C). An expression host is the organism that produces the phytase enzyme [27]. The enzyme can be expressed directly from the organism, or the genetic code that encodes for phytase can be spliced from one organism, typically a yeast, and placed into another organism, typically E. coli, that will express the enzyme [28]. This is done because E. coli can be grown very quickly and expresses high amounts of phytase [29]. The entire organism can be added to a broiler diet, or the protein can be extracted and added to the diet [30]. For these experiments, the extracted protein was used. For Experiment 2, the in vivo and in vitro feed manufacture and live bird performance was conducted similarly to Experiment 1. 


\section{Experiment 3: in vivo dosing assay using the best enzyme/host combination}

The lead candidate selected from Experiment 2 was B1; therefore this enzyme was used to design Experiment 3, a dosing experiment as the next step for proper phytase assessment. The dosing experiment utilized four different enzyme concentrations $(250,500,750,1000$ FTU/kg) along with standard diets (PC, NC, 3PC:1NC, 1PC:3NC) (Table 1). Once again, feed manufacture and live bird study were conducted identically to that described previously in Experiment 1.

\section{Experiment 4: in vivo assay using incrementally increased pelleting temperatures}

The final experiment incorporated data obtained from the previous 3 studies to assess the efficacy of the phytase in an animal model after pelleting. The dose chosen from Experiment 3 (750 FTU/kg) was utilized in feed manufactured similarly to that described in the in vitro retention assay section of Experiment 1. Four of the eight experimental treatments utilized $\mathrm{NC}+\mathrm{B} 1$ pelleted at either $75^{\circ} \mathrm{C}, 85^{\circ} \mathrm{C}, 90^{\circ} \mathrm{C}$, and one treatment included the enzyme but was kept assayed in mash (unprocessed) for a control; the other four treatments consisted of the standard diets utilized in previous experiments. All pelleted diets were ground via a roller mill prior to feeding birds to eliminate feed form effects. Bird performance and statistical analysis were conducted identically to Experiment 1.

\section{RESULTS AND DISCUSSION}

\section{Experiment 1: in vivo assays using lead candidates in mash feed}

Four novel phytase enzymes were selected for testing in this experiment to assess phytases in vivo using mash feed and comparing these data to measures of in vitro activity. Results for live bird performance are shown in Table 4. The in vitro activity results are shown in 
Table 2 and demonstrate that: 1) diets were properly mixed and 2) phytase inclusion was successful in meeting the target inclusion rate of approximately $500 \mathrm{FTU} / \mathrm{kg}$. The results from in vitro testing of enzymes $\mathrm{A}-\mathrm{D}$ in pelleted feed are shown in Figure 1.

Beginning pen weight was taken on $\mathrm{d} 3$ and no significant differences were detected. The 3-21d experimental period demonstrated significant differences for LWG $(\mathrm{P}<0.0001)$, FCR $(\mathrm{P}<$ 0.001), FI ( $\mathrm{P}<0.0001)$, TA\% $(\mathrm{P}<0.01)$, and TA mg/chick $(\mathrm{P}<0.0001)$ among broilers fed the $\mathrm{PC}$ and NC formulations. In addition, these data showed that birds fed any of the four enzyme variants performed similarly as birds fed PC $(\mathrm{P}>0.05)$, and all treatments were found to be significantly different from the NC (Table 4). A linear and quadratic regression of the standard curve was performed to calculate sparing effects; the quadratic was found to be significant and $\mathrm{R}^{2}$ values for all variables measured were higher, signifying that a quadratic fit was the superior model for the data. Therefore, nPP sparing for the quadratic regression were calculated and shown in Table 5. The highest nPP sparing associated with LWG, TA\%, and TA mg/chick were produced by Enzyme C sparing between $0.14-0.19 \%$ of nPP.

Phytase retention results determined from in vitro testing of enzymes $A-D$ is shown in Figure 1. The ambient temperature was $27.7^{\circ} \mathrm{C}$. When feed was pelleted at $75^{\circ} \mathrm{C}$, phytase retention was determined to be between $50-70 \%$, with enzyme B demonstrating the best retention. As pelleting temperature increased, retention for all enzyme variants decreased; at the highest pelleting temperature recorded, $93^{\circ} \mathrm{C}$, all variants demonstrated between $4-11 \%$ retention. Three of the enzymes $(\mathrm{A}, \mathrm{C}, \mathrm{D})$ performed the best at the lowest pelleting temperature recorded, $75^{\circ} \mathrm{C}$. Enzyme B did not begin to demonstrate decreased retention until pelleting 
temperatures reached $85^{\circ} \mathrm{C}$ and retained the highest efficacy at $93^{\circ} \mathrm{C}, 11 \%$. Feed manufacture was not replicated; therefore, results should be interpreted as descriptive data.

Treatments $\mathrm{NC}+\mathrm{B}$ and $\mathrm{NC}+\mathrm{C}$ demonstrated the best values for FI, $\mathrm{LWG}, \mathrm{TA} \%$ and the greatest $\mathrm{P}$ sparing for these variables. $\mathrm{NC}+\mathrm{B}$ and $\mathrm{NC}+\mathrm{C}$ also demonstrated the highest enzyme retention post pelleting as determined from in vitro testing. Therefore, these two enzymes were chosen for further testing.

\section{Experiment 2: Optimization of enzyme production based on a specific expression host}

Determining phytase efficacy in mash feed is a necessary first step for testing a phytase for commercial potential; however, additional factors are important. One such factor is the expression host organism; host organisms can affect enzyme efficacy by affecting $\mathrm{pH}$ optimum and sterospecificity of phytase hydrolysis (3- or 6-phytase) [31]. Therefore, a yeast and bacteria were tested to determine the optimal host for expression of the experimental phytases in Experiment 2. Once again, methodology used in Experiment 1 was utilized to test in vitro activity of mash feed (Table 2) and corresponding post pelleting in vitro retention incorporating the same enzyme variants (Figure 2).

Results of live bird performance for this expression host testing are shown in Table 6. No statistical difference was observed for D3 starting pen weights. The 3-21d experimental period demonstrated that significant differences were detected for FI $(\mathrm{P}=0.0174), \mathrm{LWG}(\mathrm{P}=$ 0.0059), TA\% (P<0.0001), and TA mg/chick $(\mathrm{P}<0.0001)$. The $\mathrm{PC}$ was found to be significantly different from the NC. For FI, LWG, and FCR all of the enzyme treatments were statistically similar to the PC. The PC and 3PC:1NC were statistically similar for TA\%, all enzyme treatments were statistically similar to the $1 \mathrm{PC}: 3 \mathrm{NC} ; \mathrm{NC}+\mathrm{C}$ and $\mathrm{NC}+\mathrm{C} 1$ was similar to 
both the 3PC:1NC and 1PC:3NC. The PC, 3PC:1NC, 1PC:3NC were statistically similar for TA mg/chick. The enzyme treatment $\mathrm{NC}+\mathrm{B}$ was statistically similar to all other treatments except the PC, 3PC:1NC, and NC. The NC+B1 and NC+C1 enzyme treatments were similar to all treatments except the NC and 3PC:1NC. A linear and quadratic regression of the standard curve was performed to obtain nPP sparing for the enzyme treatments (Table 7). Linear regression was found to be significant for LWG and TA mg/chick. Enzyme C produced the highest nPP sparing for LWG and TA mg/chick, 0.10 and $0.08 \%$, respectively. Quadratic regression was found to be significant for TA\%, with Enzyme B demonstrating the largest nPP sparing, $0.05 \%$.

Phytase retention results determined from post pelleting in vitro testing of enzymes $\mathrm{B}, \mathrm{C}$, $\mathrm{B} 1$, and $\mathrm{C} 1$ is shown in Figure 2. The ambient temperature was $28.8^{\circ} \mathrm{C}$. All 4 enzymes demonstrated the highest retention, between $60-72 \%$, when feed was pelleted at $75^{\circ} \mathrm{C}$ and decreased as conditioning temperature increased. At $80^{\circ} \mathrm{C}$ conditioning temperature, enzyme variants retained similar efficacy as $75^{\circ} \mathrm{C}$, around $60-70 \%$; when conditioning temperature increased to $85^{\circ} \mathrm{C}$ efficacy decreased by as much as $30 \%$ in the case of enzyme $\mathrm{C} 1$; at the highest temperature, $93^{\circ} \mathrm{C}$, phytase retention for all enzyme variants were determined to be $14 \%$ or lower. Feed manufacture was not replicated; therefore, results should be interpreted as descriptive data. However, phytase enzymes used in this experiment as well as Experiment 1 showed higher retained in vitro activity compared to past research using enzymes exposed to similar conditioning temperatures. In one study, phytases demonstrated decreased efficacy at $55^{\circ} \mathrm{C}$ and $60^{\circ} \mathrm{C}[32,33]$; in another study phytases tested at conditioning temperatures of $75^{\circ} \mathrm{C}$ lost most of their efficacy $[33,35]$. Two additional studies reported enzyme efficacy loss at conditioning temperatures of $70^{\circ} \mathrm{C}[36,37]$. 
From this data, $\mathrm{NC}+\mathrm{B} 1$ was chosen for testing in Experiment 3. This enzyme was chosen because it performed similar to the PC for FI, FCR, and TA\% and also demonstrated some of the highest $\mathrm{P}$ sparing for LWG, TA\%, and TA mg/chick.

\section{Experiment 3: in vivo dosing assay using the best enzyme/host combination}

From the previous experiment, a bacteria was determined to be the best host for

production of the enzyme. This led to the current experiment assessing the relationship between in vivo performance and in vitro activity assays. This is a valuable experiment to perform because a wide variation in recommended dosage for similar P release has been reported among commercially available phytases. For example, 1,850 FTU/kg of $P$. lycii-derived phytase [38] has been recommended to replace $0.1 \%$ available $\mathrm{P}$ [39]. Alternatively, it has been demonstrated that $250 \mathrm{FTU} / \mathrm{kg}$ of an E. coli-derived phytase [40], can effectively replace $0.13 \%$ available $\mathrm{P}$ in swine diets, while a different another E.coli-derived phytase [41], requires $500 \mathrm{FTU} / \mathrm{kg}$ to replace $0.12 \%$ available $\mathrm{P}[42]$.

In Experiment 3, a theoretical dosage range from 250 - 1000 FTU/kg was utilized and analytical results are reported in Table 8 with corresponding post pellet in vitro activity results reported in Table 2. Starting pen weights demonstrated no significant differences; however, differences were detected for FI ( $\mathrm{P}<0.0001)$, LWG $(\mathrm{P}<0.0001)$, and FCR $(\mathrm{P}<0.0001)$. For FI, the PC, 3PC:1NC, NC+B1 (750 FTU/kg) and NC+ B1 (1000 FTU/kg) treatments performed the best, with the NC performing the worst. PC, 3PC:1NC, NC+B1 (500 FTU/kg), NC+B1 (750 FTU/kg), and NC+B1 (1000 FTU/kg) were statistically similar for LWG; all treatments were statistically different from the NC for FCR. The PC, 3PC:1NC, NC+B1 (750 FTU/kg), and NC+B1 (1000 FTU/kg) demonstrated similar TA\%; when the TA mg/chick was determined, 
there was a step-wise progression, where $\mathrm{mg} / \mathrm{chick}$ increased as the enzyme dose increased. Once again, a linear and quadratic regression on the standard curve was performed to obtain sparing effects for the enzyme treatments (Table 9). In this experiment, all variables were found to be significant for the quadratic regression with corresponding high $\mathrm{R}^{2}$ values. Chicks fed the $\mathrm{NC}+\mathrm{B} 1(1000 \mathrm{FTU} / \mathrm{kg})$ diet produced the largest nPP sparing for LWG, FI, FCR, TA\%, and TA mg/chick. These nPP sparing effects ranged from 0.04 to $0.20 \%$ of nPP. The chicks fed the $\mathrm{NC}+\mathrm{B} 1(750 \mathrm{FTU} / \mathrm{kg})$ diet produced the next highest nPP sparing for all variables measured, ranging from 0.04 to $0.14 \%$ of $\mathrm{nPP}$.

From this data, a dose of $750 \mathrm{FTU} / \mathrm{kg}$ was chosen as the goal dose for the next experiment. This dose was chosen because with the exception of TA mg/chick measure, birds fed this treatment performed similarly to $\mathrm{NC}+\mathrm{B} 1$ (1000 FTU/kg) fed birds. In addition, the authors felt that an enzyme concentration of $1000 \mathrm{FTU} / \mathrm{kg}$ may be too high to demonstrate sensitivity to thermal denaturation associated with pelleting. Therefore, 750 FTU/kg was chosen as the goal enzyme concentration.

\section{Experiment 4: in vivo assay using incrementally increased pelleting temperatures}

Using in vivo data collected in Experiment 3 and post pelleted in vitro retention data from Experiments 1 and 2, the most successful dose and three most crucial pelleting temperatures were determined and used for Experiment 4. This experiment was important due to the fact that high enzyme retention post pelleting determined in vitro may not translate to high efficacy in vivo [43]. Most past research has viewed in vitro post pellet activity and in vivo pelleted phytase efficacy as separate experiments; demonstrating high activity in vitro post 
pelleting without correlating in vivo testing of efficacy [44] or in vivo testing of efficacy using mash without corresponding in vitro post pelleting activity [45].

The data generated from the in vivo testing is reported in Table 10 and in vitro post pelleted activity is reported in Table 3. Significant differences were detected for feed intake $(\mathrm{P}<$ 0.0001), LWG $(\mathrm{P}<0.0001)$, FCR $(\mathrm{P}<0.0001)$, TA\% $(\mathrm{P}<0.0001)$, and TA mg/chick $(\mathrm{P}<$ 0.0001). Birds fed the $\mathrm{NC}+\mathrm{B} 1$ pelleted at $85^{\circ} \mathrm{C}$ and $90^{\circ} \mathrm{C}$ demonstrated the highest values for FI. $\mathrm{NC}+\mathrm{B} 1$ pelleted at $85^{\circ} \mathrm{C}$ demonstrated the greatest LWG. The NC demonstrated the worst FCR, while the NC+B1 mash demonstrated the best FCR compared to the other enzyme treatments. The PC, 3PC:1NC, and NC+B1 in mash demonstrated the highest TA\% and mg/chick values; $\mathrm{NC}+\mathrm{B} 1$ pelleted at $85^{\circ} \mathrm{C}$ and $90^{\circ} \mathrm{C}$ were statistically similar to $\mathrm{NC}(\mathrm{P}>0.05)$. Birds fed treatments that were conditioned at high temperatures demonstrated larger LWG and lowered FCR, TA data suggests that birds fed these diets were unable to utilize the phosphorus in their diets, as shown by the lower TA measurements.

A linear and quadratic regression of the standard curve was performed to obtain nPP sparing for the enzyme treatments and the quadratic regression was found to be the best fit model. The nPP sparing is shown in Table 11. Birds fed diets pelleted at $75^{\circ} \mathrm{C}$ produced the highest sparing effects for LWG and FI (0.12 and $0.06 \%$ of nPP, respectively). Birds fed $\mathrm{NC}+\mathrm{B} 1$ in mash diets at the same enzyme concentration demonstrated higher nPP sparing for FCR, TA\%, and TA mg/chick than birds fed any of the pelleted diets $(0.11-0.12 \%$ of $\mathrm{nPP})$. These data suggest that any heat treatment (as low as $75^{\circ} \mathrm{C}$ ) can be detrimental to this particular phytase enzyme. Further production modifications are necessary to maximize this enzymes thermal stability prior to field testing. 


\section{CONCLUSIONS AND APPLICATIONS}

1) This study outlines some of the many factors that must be considered prior to commercializing a phytase enzyme, including: using mash feed, expression host, dosing assay, using pelleted feed, determining in vitro post pelleting activity and retention. All of these factors affected the phytases used in these experiments.

2) No clear phytase candidate has been chosen; more research needs to be conducted and includes: testing the enzyme carrier and properties of the carrier (carrier granule particle size), and continuing in vitro retention assays and in vivo animal experiments to determine how phytases function under the conditions associated with pelleting.

3) Both in vitro post pellet activity and in vivo testing of phytases must be considered to properly determine the enzyme that best performs under the aforementioned factors and can be targeted for commercialization.

\section{REFERENCES AND NOTES}

1) N.P. Buchanan, K.G.S. Lilly, C.K. Gehring, and J.S. Moritz. The effects of altering diet formulation and manufacturing technique on pellet quality. J. Appl. Poult. Res. 2010 19:112-120.

1) Behnke, K. C. 1996. Feed manufacturing technology: Current issues and challenges. Anim. Feed Sci. Technol. 62: 49 - 57.

2) Karim, A. A, M. H. Norziah, and C. C. Seow. 2000. Methods for the study of starch retrogradation. Food Chem. 71: 9 -36.

3) Zaritzky, N. E. 2000. Physical and microstructural properties of frozen gelatinized starch suspensions. Pages 15 - 28 on Trends in Food Engineering. Lozano, J. E., C. Anon, E. Parada-Arias, and G. V. Barbosa-Canovas, eds. CRC press, Boca Raton, FL.

4) Lund, D. 1984. Influence of time, temperature, moisture, ingredients, and processing conditions on starch gelatinization. Crit. Rev. Food Sci. Nutr. 20: 249 - 273. 
5) Briggs, J. L., D. E. Maier, B. A. Watkins, and K. C. Behnke. 1999. Effect of ingredients and processing parameters on pellet quality. Poult. Sci. 78: $1464-1471$.

6) Renkema, J. M. S., C. M. M. Lakemond, H. H. J. de Jongh, H. Gruppen, and T. van Vliet. 2000. The effect of $\mathrm{pH}$ on heat denaturation and gel performing properties of soy proteins. J. Biotech. 79: $223-230$.

7) Payne, R. L., T. K. Lavergne, and L. L. Southern. 2005. A comparison of two sources of phytase in liquid and dry forms in broilers. Poult. Sci. 84: $265-272$.

8) Greiner R, U. Kontietzny, K.D. Jany. 1993. Purification and characterization of two phytases from Escherichia coli. Arch. Biochem. Biophys. 303: 107-113.

9) Golovan, S.P., G. Wang, J. Zhang, and C.W. Forsberg. 2000. Characterisation and overproduction of the Escherichia coli appA encoded bifunctional enzyme that exhibits both phytase and acid phosphatase activities. Can. J. Microbiol. 46: $59-71$.

10) Lei, X., C. H. Stahl. 2001. Biotechnology development of effective phytases for mineral nutrition and environmental protection. Appl. Micro. Biotech. 57: $474-481$.

11) Gehring, C. K., K. G. S. Lilly, L. K. Shires, K. R. Beaman, S. A. Loop, and J. S. Moritz. 2010. Increasing mixer-added fat reduces the electrical energy required for pelleting and improves exogenous enzyme efficacy for broilers. J. Appl. Poult. Res. (Accepted).

12) Vertical mixer, Avery Weigh-Tronix, Fairmont, MN.

13) Hobart paddle mixer (model 4146) Hobart Corp., Troy, OH.

14) Eurofins Scientific, Des Moines, IA.

15) Farzinpour, A., A. Karimi, and A. S. Ahmadi. 2011. Effects of dietary phytase and different levels of non-phytate phosphorus on serum minerals and biochemical parameters in broiler chickens. J. Anim. Vet. Adv. 10: 1317 - 1321.

16) Jones, C. K., M. D. Tokach, B. W. Ratliff, N. L. Horn, S. S. Dritz, R. D. Goodband, J. M. DeRouchey, and J. L. Nelssen. Efficacy of different commercial phytase sources and development of a phosphorus release curve. Nursery Pig Nutrit. And Manag. 106 - 121.

17) Jiang, S., Z. Jiang, G. Zhou, and Z. Chen. 2011. Non-phytate phosphorus requirements and efficacy of a genetically engineered yeast phytase in yellow broilers from 1 to 21 days of age. J. Anim. Phys. Anim. Nutr. 95: $47-55$.

18) AOAC. 2000. Method 2000.12. Phytase activity in feed: colorimetric enzymatic method. In official methods of analysis of AOAC international. $17^{\text {th }}$ ed. Assoc. Off. Anal. Chem., Arlington VA. 
19) Ravindran, V., S. Cabahug, G. Ravindran, and W. L. Bryden. 1999. Influence of microbial phytase on apparent ileal amino acid digestibility of feedstuffs for broilers. Poult. Sci. 78: 699 - 706.

20) Cobb-Vantress, Siloam Springs, AR. 2008.

21) Matterns Hatchery, Beaver Springs, PA.

22) A 4.25 feet length, 1.02 feet diameter short term California Pellet Mill conditioner (3 steam inlet ports), 429 rpm shaft speed; 21 picks; 10 -s feed retention time.

23) Master Model Pellet Mill, California Pellet Mills Company, Crawfordsville, IN.

24) A 10 feet length horizontal belt cooler.

25) SAS Institute. 2000. The SAS System for Windows 2000. Release 8.1. SAS Inst. Inc., Cary, NC.

26) Konietzny U, Greiner R (2002). "Molecular and catalytic properties of phytate-degrading enzymes (phytases)". Int J Food Sci Technol 37: 791-812

27) Xuan, N. T., M. T. Hang, and V. N. Thanh. 2009. Cloning and over expression of and Aspergillus niger XP phytase gene in Pichia pastoris. World Acad. Of Sci., Engineer. And Technol. 56: $750-753$.

28) Viveros, A., C. Centeno, A. Brenes, R. Canales, and A. Lozano. 2000. Phytase and acid phosphatase activities in plant feedstuffs. J. Agric. Food Chem. 48:4009-4013.

29) Lei, X. G., and J. M. Porres. 2003. Phytase enzymology, applications, and biotechnology. Biotech. Letters. 25: $1787-1794$.

30) Adeola, O., J. S. Sands, P. H. Simmins, and H. Schulze. 2004. The efficacy of an Escherichia coli-derived phytase preparation. J. Anim. Sci. 82: 2657- 2666.

31) Pandey, A., G. Szakacs, C. R. Soccol, J. A. Rodriguez-Leon, and V. T. Soccol. 2001. Production, purification, and properties of microbial phytases. Biores. Technol. 77: 203 214.

32) Kirkpinar, F., H. Basmacioglu. 2006. Effects of pelleting temperature of phytase supplemented broiler feed on tibia mineralization, calcium, and phosphorus content of serum and performance. Czech Journal of Animal Science. 51: 78-84.

33) Hughes, A., 1993. Importance of phytates and cereal phytases in the feeding of pigs. Enzymes in Animal Nutrition. C Wenk, ed. ETH-Zurich, Zurich. pp. 192 -198. 
34) Wyss, M., Pasamontes,L., Remy,R., Kohler, J., Kusznir, E., Gadient, M., Muller,F., and VanLoon, A.P.G.M. (1998) Comparision of the thermostability properties of three acid phosphatases from molds: Aspergillus fumigates phytase, A. niger phytase, and A. niger pH 2.5 acid phosphatase . Applied and Environmental Microbiology 64: 4446-4451.

35) Jongbloed, A.W., and P. A. Kemme. 1990. Effect of pelleting mixed feeds on phytate activity and apparent absorbability of phosphorus and calcium in pigs. Animal Feed Sci. Tech. 28:233-242.

36) Kim, Y.O., H.K. Kim, K.S. Bae, J.H. Yu, and T.K. Oh. 1998. Purification and properties of a thermostable phytase from Bacillus spp. Enzyme Microb. Technol. 22: $2-7$.

37) Ronozyme P, DSM Nutritional Products, Basel, Switzerland.

38) Jones, C. K., M. D. Tokach, S. S. Dritz, B. W. Ratliff, N. L. Horn, R. D. Goodband, J. M. DeRouchey, R. C. Sulabo, and J. L. Nelssen. 2010. Efficacy of different commercial phytase enzymes and development of an available phosphorus curve for Escherichia coliderived phytases in nursery pigs. J. Anim. Sci. 88: 3631 - 3644.

39) Phytex LLC, Sheridan, IN

40) Danisco Animal Nutrition, Marlborough, UK

41) Jendza, J. A., R. N. Dilger, J. A. Sands, and O. Adeola. 2006. Efficacy and equivalency of an Escherichia coli-derived phytase for replacing inorganic phosphorus in the diets of broiler chickens and young pigs. J. Anim. Sci. 84: 3364 - 3374.

42) Loop, S. A., K. G. S. Lilly, L. K. Shires, C. K. Gehring, K. R. Beaman, M. E. Persia, and J. S. Moritz. Phytase analytical activity of pelleted diets may not adequately describe efficacy in the bird. J. Appl. Poult. Res. (In Press)

43) Pasamontes, L., M. Haiker, M. Wyss, M. Tessier, and A. P. G. M. vanLoon. 1997. Gene cloning, purification, and characterization of a heat-stable phytase from the fungus Aspergillus fumigatus. Appl. Enivon. Microbio. 63: 1696 - 1700.

44) Timmons, J. R., R. Angel, J. M. Harter-Dennis, W. W. Saylor, and N. E. Ward. 2008. Evaluation of heat-stable phytases in pelleted diets fed to broilers from day zero to thirty five during the summer months. J. Appl. Poult. Res. 17: $482-489$. 
Table 1. Diet formulations for positive and negative control diets

\begin{tabular}{|c|c|c|}
\hline Ingredients & Positive control & Negative control \\
\hline & \multicolumn{2}{|c|}{$\%$ Inclusion } \\
\hline Corn & 53.19 & 53.12 \\
\hline Soybean meal (48\%) & 35.29 & 35.38 \\
\hline Corn DDGS & 5.00 & 5.00 \\
\hline Soybean oil & 3.00 & 3.00 \\
\hline Tricalcium phosphate & 1.74 & 0.63 \\
\hline Limestone & 0.68 & 1.64 \\
\hline DL-methionine & 0.29 & 0.29 \\
\hline Vitamin mineral premix $^{1}$ & 0.25 & 0.25 \\
\hline Lysine & 0.13 & 0.13 \\
\hline Salt & 0.2 & 0.33 \\
\hline Threonine & 0.11 & 0.11 \\
\hline Coban $60^{2}$ & 0.08 & 0.08 \\
\hline $\mathrm{BMD}^{3}$ & 0.05 & 0.05 \\
\hline \multicolumn{3}{|c|}{ Calculated Nutrients } \\
\hline $\mathrm{ME}(\mathrm{kcal} / \mathrm{kg})$ & 3030.5 & 3030.5 \\
\hline Crude protein $(\%)$ & 23.48 & 23.51 \\
\hline Lysine (\%) & 1.18 & 1.18 \\
\hline Methionine + cystine $(\%)$ & 0.89 & 0.89 \\
\hline Threonine $(\%)$ & 0.75 & 0.75 \\
\hline Calcium (\%) & 0.91 & 0.91 \\
\hline Non-phytate phosphorus (\%) & 0.45 & 0.25 \\
\hline Sodium $(\%)$ & 0.20 & 0.20 \\
\hline \multicolumn{3}{|c|}{ Analyzed Nutrients } \\
\hline Crude Protein $(\%)$ & 21.80 & 21.80 \\
\hline Calcium (\%) & 0.86 & 0.87 \\
\hline Non-phytate phosphorus (\%) & 0.42 & 0.25 \\
\hline
\end{tabular}

${ }^{1}$ Supplied per kg of diet: manganese, $0.02 \%$; zinc $0.02 \%$; iron, $0.01 \%$; copper, $0.0025 \%$; iodine, $0.0003 \%$; selenium, $0.00003 \%$; folic acid, $0.69 \mathrm{mg}$; choline, 386mg' riboflavin, $6.61 \mathrm{mg}$; biotin, $0.03 \mathrm{mg}$; vitamin B6, 1.38mg; niacin, 27.56mg; pantothenic acid, $6.61 \mathrm{mg}$; thiamine, 2.20mg; manadione, 0.83mg; vitamin B12, 0.01mg; vitamin E, 16.53 IU; vitamin D3, 2133 ICU; vitamin A, 7716 IU.

${ }^{2}$ Active drug ingredient Monensin Sodium $60 \mathrm{gpb}$ (90 g/ton inclusion), Elanco Animal Health, Indianapolis, IN. As an aid in the prevention of coccidiosis caused by Eimerianecarix, Eimeriatenella, Eimeriaacervulina, Eimeria brunette, Eimeriamivati, and Eimeria maxima.

${ }^{3}$ Bacitracin Methylene Disalicylate $50 \mathrm{~g} / \mathrm{lb}$ (50 g/ton inclusion), Alpharma, Fort Lee, NJ. For increased rate of weight gain and improved feed efficiency. 
1 Table 2. Phytase activity for Experiments 1, 2, $3^{1}$ using the AOAC 2000.12 method

\begin{tabular}{|c|c|}
\hline Treatment & Phytase Activity (FTU/kg) \\
\hline \multicolumn{2}{|c|}{ Experiment 1 (goal enzyme concentration $=500 \mathrm{FTU} / \mathrm{kg})$} \\
\hline $\mathrm{NC}+\mathrm{A}$ & 689 \\
\hline $\mathrm{NC}+\mathrm{B}$ & 836 \\
\hline $\mathrm{NC}+\mathrm{C}$ & 869 \\
\hline $\mathrm{NC}+\mathrm{D}$ & 701 \\
\hline \multicolumn{2}{|c|}{ Experiment 2 (goal enzyme concentration $=500 \mathrm{FTU} / \mathrm{kg}$ ) } \\
\hline $\mathrm{NC}+\mathrm{B}$ & 210 \\
\hline $\mathrm{NC}+\mathrm{C}$ & 270 \\
\hline $\mathrm{NC}+\mathrm{B} 1$ & 280 \\
\hline $\mathrm{NC}+\mathrm{C} 1$ & 260 \\
\hline \multicolumn{2}{|c|}{ Experiment 3} \\
\hline $\begin{array}{c}\mathrm{NC}+\mathrm{B} 1 \\
(\text { goal enzyme concentration }=250 \mathrm{FTU} / \mathrm{kg} \text { ) }\end{array}$ & 280 \\
\hline $\begin{array}{c}\mathrm{NC}+\mathrm{B} 1 \\
\text { (goal enzyme concentration }=500 \mathrm{FTU} / \mathrm{kg} \text { ) }\end{array}$ & 380 \\
\hline $\begin{array}{c}\mathrm{NC}+\mathrm{B} 1 \\
\text { (goal enzyme concentration }=750 \mathrm{FTU} / \mathrm{kg} \text { ) }\end{array}$ & 620 \\
\hline $\begin{array}{c}\mathrm{NC}+\mathrm{B} 1 \\
(\text { goal enzyme concentration }=1000 \mathrm{FTU} / \mathrm{kg})\end{array}$ & 870 \\
\hline
\end{tabular}


Table 3. Phytase activity ${ }^{1}$ and retention for Experiment 4: in vivo assay using increasing pelleting temperature.

\begin{tabular}{|c|c|c|c|c|}
\hline Treatment & $\begin{array}{c}\text { Pelleting Temperature } \\
\left({ }^{\circ} \mathbf{C}\right)\end{array}$ & $\begin{array}{c}\text { Phytase Activity } \\
\text { (FTU/kg) } \\
\text { Mash Feed }\end{array}$ & $\begin{array}{c}\text { Phytase Activity } \\
(\text { FTU/kg) } \\
\text { Pellet Feed }\end{array}$ & $\begin{array}{c}\text { Phytase Retention } \\
(\%)\end{array}$ \\
\hline NC+B1 & 75 & 600 & 410 & 68.33 \\
\hline NC+B1 & 85 & 660 & 430 & 65.15 \\
\hline NC+B1 & 90 & 750 & 150 & 20.00 \\
\hline NC+B1 & Not pelleted & 770 & ----- & ---- \\
\hline
\end{tabular}

${ }^{1}$ Phytase activity was determined using the AOAC 2000.12 method. 
Table 4. Experiment 1: The effect of four lead candidate phytase enzymes utilized in mash feed on live bird performance

\begin{tabular}{|c|c|c|c|c|c|c|c|}
\hline Treatment $^{1}$ & $\begin{array}{c}\text { Day } 3 \\
\text { Starting pen } \\
\text { weight }^{2}(\mathrm{~kg}) \\
\end{array}$ & $\begin{array}{c}\text { Day 3-21 } \\
\text { Pen Feed } \\
\text { Intake (kg) }\end{array}$ & $\begin{array}{c}\text { Day 3-21 } \\
\text { FCR }^{3} \\
(\mathrm{~kg} / \mathrm{kg}) \\
\end{array}$ & $\begin{array}{c}\text { Day 3-21 } \\
\text { LWG }^{4} \\
\text { (kg/bird) }\end{array}$ & $\begin{array}{c}\text { Percent } \\
\text { Mortality } \\
(\%) \\
\end{array}$ & $\begin{array}{c}\text { Tibia Ash } \\
\text { (mg/chick) }\end{array}$ & $\begin{array}{c}\text { Tibia Ash } \\
(\%)\end{array}$ \\
\hline $\begin{array}{c}\mathrm{NC} \\
\left(0.20 \mathrm{nPP}^{5}\right)\end{array}$ & 0.427 & $1.11^{\mathrm{c}}$ & $2.23^{\mathrm{a}}$ & $0.09^{\mathrm{c}}$ & $42.37^{\mathrm{a}}$ & $94.44^{\mathrm{c}}$ & $14.64^{b}$ \\
\hline $\begin{array}{c}\text { 1PC:3NC } \\
(0.24 \text { nPP) }\end{array}$ & 0.446 & $2.10^{\mathrm{ab}}$ & $1.76^{b}$ & $0.15^{b}$ & $7.42^{b}$ & $168.84^{\mathrm{a}}$ & $17.36^{\mathrm{a}}$ \\
\hline $\begin{array}{l}\text { 3PC:1NC } \\
(0.37 \text { nPP) }\end{array}$ & 0.426 & $2.20^{\mathrm{ab}}$ & $1.63^{b}$ & $0.17^{\mathrm{ab}}$ & $7.11^{b}$ & $173.77^{\mathrm{a}}$ & $17.35^{\mathrm{a}}$ \\
\hline $\begin{array}{c}\text { PC } \\
(0.41 \mathrm{nPP})\end{array}$ & 0.426 & $2.11^{\mathrm{ab}}$ & $1.64^{b}$ & $0.17^{\mathrm{ab}}$ & $11.25^{\mathrm{b}}$ & $182.13^{\mathrm{a}}$ & $17.86^{\mathrm{a}}$ \\
\hline $\mathrm{NC}+\mathrm{A}$ & 0.426 & $1.99^{b}$ & $1.72^{\mathrm{b}}$ & $0.15^{b}$ & $6.37^{b}$ & $143.82^{b}$ & $14.19^{b}$ \\
\hline $\mathrm{NC}+\mathrm{B}$ & 0.432 & $2.30^{\mathrm{a}}$ & $1.66^{b}$ & $0.17^{\mathrm{ab}}$ & $4.87^{b}$ & $176.04^{\mathrm{a}}$ & $16.59^{b}$ \\
\hline $\mathrm{NC}+\mathrm{C}$ & 0.425 & $2.50^{\mathrm{a}}$ & $1.64^{b}$ & $0.19^{\mathrm{a}}$ & $0.00^{c}$ & $190.31^{\mathrm{a}}$ & $18.67^{\mathrm{a}}$ \\
\hline $\mathrm{NC}+\mathrm{D}$ & 0.427 & $2.16^{\mathrm{ab}}$ & $1.72^{\mathrm{b}}$ & $0.15^{b}$ & $3.25^{\mathrm{b}}$ & $154.08^{\mathrm{ab}}$ & $17.58^{\mathrm{a}}$ \\
\hline $\begin{array}{l}\text { ANOVA } \\
\text { P-Value } \\
\end{array}$ & 0.5927 & $<0.0001$ & $<0.0001$ & $<0.0001$ & $<0.0001$ & $<0.0001$ & 0.0116 \\
\hline SEM $^{6}$ & 0.0025 & 0.0912 & 0.0638 & 0.0079 & 3.8789 & 7.5673 & 0.8993 \\
\hline $\begin{array}{c}\text { Fisher's } \\
\text { LSD }^{7}\end{array}$ & ------- & 0.0665 & 0.0326 & 0.0005 & 120.368 & 47.543 & 1.432 \\
\hline
\end{tabular}

${ }^{1}$ Treatments $0.20,0.24,0.37,0.41$ describes the calculated non-phytate phosphorus percentage. Enzyme A - D are lead phytase candidates chosen from Experiment 1 : in vitro activity.

${ }_{3}^{2}$ Starting pen weight based on 8 birds per pen

${ }^{3}$ Feed Conversion Ratio (Feed:Gain) was calculated using mortality weight

Live Weight Gain

Non-phytate phosphorus is calculated by total phosphorus - $(0.282 \mathrm{X}$ phytic acid $)$

${ }^{6}$ Standard Error of the Mean

'Fisher's Least Significant Difference

${ }^{\text {a-d }}$ Means within a column not sharing a common superscript differ $(\mathrm{P}<0.05)$ 
Table 5. Experiment 1: in vivo assay utilizing mash feed. Sparing effects calculated from the standard quadratic

31 regression using tricalcium phosphate.

\begin{tabular}{|c|c|c|c|c|c|c|c|c|}
\hline Treatment $^{1}$ & $\begin{array}{c}\text { Derived } \\
\text { Calc P }(\%) \\
\text { LWG }^{4}\end{array}$ & $\begin{array}{c}\text { LWG \% P } \\
\text { sparing } \\
\text { effect }^{3}\end{array}$ & $\begin{array}{c}\text { Derived } \\
\text { Calc P }(\%) \\
\text { FCR }^{4}\end{array}$ & $\begin{array}{c}\text { FCR \% P } \\
\text { sparing } \\
\text { effect }^{3}\end{array}$ & $\begin{array}{l}\text { Derived Calc P } \\
\text { (\%) Tibia Ash }\end{array}$ & $\begin{array}{c}\text { Tibia Ash \% } \\
\text { P sparing }_{\text {effect }^{3}}\end{array}$ & $\begin{array}{c}\text { Derived Calc P }(\%) \\
\text { Tibia Ash } \\
(\mathrm{mg} / \text { chick })^{6}\end{array}$ & $\begin{array}{c}\text { Tibia Ash } \\
\text { (mg/chick) \% P } \\
\text { sparing effect }^{3}\end{array}$ \\
\hline $\mathrm{NC}+\mathrm{A}$ & 0.29 & 0.09 & 0.31 & 0.11 & 0.20 & 0.00 & 0.26 & 0.06 \\
\hline $\mathrm{NC}+\mathrm{B}$ & 0.34 & 0.14 & 0.33 & 0.13 & 0.25 & 0.05 & 0.33 & 0.13 \\
\hline $\mathrm{NC}+\mathrm{C}$ & 0.39 & 0.19 & 0.34 & 0.14 & 0.38 & 0.18 & 0.36 & 0.16 \\
\hline $\mathrm{NC}+\mathrm{D}$ & 0.29 & 0.09 & 0.30 & 0.10 & 0.36 & 0.16 & 0.30 & 0.10 \\
\hline
\end{tabular}

${ }^{1}$ Enzymes A - D are lead phytase candidates chosen for testing.

$33{ }^{2}$ Calculated $\mathrm{nPP}$ values derived from the quadratic regression of LWG percent for the standard curve

$34\left[-3.53 \pm \sqrt{3.53^{2}-4(-5.24)(-0.40-L W G)}\right] / 2(-5.24)=$ calc. $n P P, \mathrm{R}^{2}=0.48$

$35 \quad$ Sparing effect based on tricalcium phosphate

$36{ }^{4}$ Calculated $\mathrm{nPP}$ values derived from the quadratic regression of FCR percent for the standard curve

$37\left[23.18 \pm \sqrt{-23.18^{2}-4(34.21)(5.45-F C R)}\right] / 2(34.21)=$ calc. $\mathrm{nPP}, \mathrm{R}^{2}=0.57$

$38{ }^{5}$ Calculated nPP values derived from the quadratic regression of Tibia Ash \% percent for the standard curve

$39\left[-103.73 \pm \sqrt{103.73^{2}-4(-152.23)(-12.43-\text { Tibia Ash Percent })}\right] / 2(-152.23)=$ calc. $n P P, R^{2}=0.51$

$40{ }^{6}$ Calculated nPP values derived from the quadratic regression of Tibia Ash mg/chick percent for the standard curve

$41\left[-3124.91 \pm \sqrt{3124.91^{2}-4(-4618.19)\left(-335.17-\text { Tibia Ash } \frac{\mathrm{mg}}{\text { chick }}\right)}\right] / 2(-4618.19)=$ calc. $n P P, R^{2}=0.78$ 


\begin{tabular}{|c|c|c|c|c|c|c|c|}
\hline Treatment $^{1}$ & $\begin{array}{c}\text { Day } 3 \text { Starting } \\
\text { Pen Weight }{ }^{2} \\
(\mathrm{~kg})\end{array}$ & $\begin{array}{c}\text { Day 3-21 } \\
\text { Pen Feed } \\
\text { Intake (kg) }\end{array}$ & $\begin{array}{c}\text { Day 3-21 } \\
\text { FCR }^{3} \\
(\mathrm{~kg} / \mathbf{k g}) \\
\end{array}$ & $\begin{array}{c}\text { Day 3-21 } \\
\text { LWG }^{4}(\mathrm{~kg})\end{array}$ & $\begin{array}{c}\text { Percent } \\
\text { Mortality } \\
(\%)\end{array}$ & $\begin{array}{c}\text { Tibia Ash } \\
\text { (mg/chick) }\end{array}$ & $\begin{array}{c}\text { Tibia Ash } \\
\text { (\%) }\end{array}$ \\
\hline $\begin{array}{c}\mathrm{NC} \\
\left(0.28 \mathrm{nPP}^{5}\right)\end{array}$ & 0.067 & $5.04^{\mathrm{c}}$ & 1.68 & $0.382^{c}$ & 1.56 & $426.66^{\mathrm{d}}$ & $24.80^{\mathrm{d}}$ \\
\hline $\begin{array}{c}\text { 1PC:3NC } \\
(0.33 \text { nPP) }\end{array}$ & 0.067 & $5.53^{\mathrm{ab}}$ & 1.69 & $0.432^{\mathrm{ab}}$ & 6.25 & $512.69^{\mathrm{c}}$ & $28.89^{\mathrm{abc}}$ \\
\hline $\begin{array}{l}\text { 3PC:1NC } \\
(0.41 \text { nPP) }\end{array}$ & 0.067 & $5.98^{\mathrm{a}}$ & 1.74 & $0.433^{\mathrm{ab}}$ & 0.00 & $561.45^{\mathrm{ab}}$ & $30.51^{\mathrm{a}}$ \\
\hline $\begin{array}{c}\text { PC } \\
(0.43 \text { nPP }) \\
\end{array}$ & 0.067 & $5.69^{\mathrm{ab}}$ & 1.71 & $0.450^{\mathrm{a}}$ & 6.473 & $577.64^{\mathrm{a}}$ & $29.86^{\mathrm{ab}}$ \\
\hline $\mathrm{NC}+\mathrm{B}$ & 0.067 & $5.49^{\mathrm{bc}}$ & 1.71 & $0.426^{\mathrm{ab}}$ & 6.25 & $513.13^{\mathrm{c}}$ & $29.03^{\mathrm{abc}}$ \\
\hline $\mathrm{NC}+\mathrm{C}$ & 0.067 & $5.55^{\mathrm{ab}}$ & 1.65 & $0.434^{\mathrm{ab}}$ & 4.69 & $521.30^{\mathrm{bc}}$ & $27.53^{\mathrm{c}}$ \\
\hline $\mathrm{NC}+\mathrm{B} 1$ & 0.067 & $5.26^{\mathrm{bc}}$ & 1.73 & $0.402^{\mathrm{bc}}$ & 4.69 & $492.89^{c}$ & $28.36^{\mathrm{bc}}$ \\
\hline $\mathrm{NC}+\mathrm{C} 1$ & 0.067 & $5.45^{\mathrm{bc}}$ & 1.71 & $0.426^{\mathrm{ab}}$ & 6.25 & $517.55^{\mathrm{bc}}$ & $28.73^{\mathrm{bc}}$ \\
\hline $\begin{array}{l}\text { ANOVA } \\
\text { P-value }\end{array}$ & 0.3782 & 0.0174 & 0.8179 & 0.0059 & 0.2427 & $<0.0001$ & $<0.0001$ \\
\hline SEM $^{6}$ & 0.0002 & 0.1676 & 0.0383 & 0.0117 & 2.0999 & 16.0265 & 0.6015 \\
\hline Fisher's LSD ${ }^{7}$ & ----------- & 0.4762 & ----------- & 0.0334 & --------- & 45.547 & 1.7095 \\
\hline
\end{tabular}

Table 6. Experiment 2: The effect of optimized enzyme production based on specific expression host on live bird performance

\footnotetext{
${ }^{1}$ Treatments $0.28,0.33,0.41,0.43$ describes the
${ }_{3}^{2}$ Starting pen weight based on 8 birds per pen

3 Feed Conversion Ratio (Feed:Gain) was calculated using mortality weight

${ }^{4}$ Live Weight Gain

${ }^{5}$ Non-phytate phosphorus is calculated by total phosphorus - $(0.282 \mathrm{X}$ phytic acid $)$

${ }^{6}$ Standard Error of the Mean

${ }^{7}$ Fisher's Least Significant Difference

${ }^{\mathrm{a}-\mathrm{d}}$ Means within a column not sharing a common superscript differ $(\mathrm{P}<0.05)$
} 
48 Table 7. Experiment 2: Optimized phytase production based on specific expression host. Sparing effects calculated 49 from the standard linear and quadratic regression using tricalcium phosphate.

\begin{tabular}{|c|c|c|c|c|c|c|}
\hline Treatment $^{1}$ & $\begin{array}{c}\text { Linear derived } \\
\text { Calc nPP }(\%) \\
\text { LWG }^{2}(\mathbf{k g})\end{array}$ & $\begin{array}{c}\text { LWG (kg) } \\
\text { nPP Sparing }^{\text {Effect }^{3}}\end{array}$ & $\begin{array}{c}\text { Linear derived } \\
\text { Calc nPP (\%) } \\
\text { Tibia Ash } \\
\text { (mg/chick) }\end{array}$ & $\begin{array}{c}\text { Tibia Ash } \\
\text { (mg/chick) } \\
\text { nPP Sparing } \\
\text { Effect }^{3}\end{array}$ & $\begin{array}{c}\text { Quadratic } \\
\text { derived Calc } \\
\text { nPP }(\%) \text { Tibia } \\
\text { Ash }^{5} \\
(\%) \\
\end{array}$ & $\begin{array}{c}\text { Tibia Ash } \\
\text { (\%) nPP } \\
\text { Sparing } \\
\text { Effect }^{3}\end{array}$ \\
\hline $\mathrm{NC}+\mathrm{B}$ & 0.37 & 0.08 & 0.36 & 0.07 & 0.33 & 0.05 \\
\hline $\mathrm{NC}+\mathrm{C}$ & 0.39 & 0.10 & 0.36 & 0.08 & 0.31 & 0.03 \\
\hline $\mathrm{NC}+\mathrm{B} 1$ & 0.37 & 0.08 & 0.36 & 0.08 & 0.33 & 0.04 \\
\hline $\mathrm{NC}+\mathrm{Cl}$ & 0.03 & 0.02 & 0.33 & 0.05 & 0.32 & 0.04 \\
\hline
\end{tabular}

1 Enzyme B, C, B1, C1 are phytase candidates expressed in a bacteria or yeast host.

${ }^{2}$ Calculated $n P P$ values derived from the linear regression of $L W G$ for the standard curve $(L W G-0.29) / 0.37=$ calc. $n P P, R^{2}=0.30$

Sparing effect based on tricalcium phosphate

${ }^{4}$ Calculated nPP values derived from the linear regression of Tibia Ash (mg/chick) for the standard curve $($ Tibia Ash $(\mathrm{mg} / \mathrm{chick})-178.77) / 940.25=\mathrm{calc} . \mathrm{nPP}, \mathrm{R}^{2}=0.57$

${ }^{5}$ Calculated nPP values derived from the quadratic regression of Tibia Ash percent for the standard curve

$\left[-378.76 \pm \sqrt{378.76^{2}-4(-485.58)(-43.20-\text { Tibia Ash })}\right]$

$$
\text { 2(-485.58) }=\text { calc. } n P P, R^{2}=0.61
$$


Table 8. Experiment 3: The effect of enzyme dosing levels on the best phytase enzyme/host combination measured through live bird performance

\begin{tabular}{|c|c|c|c|c|c|c|c|}
\hline Treatment $^{1}$ & $\begin{array}{c}\text { Day } 3 \text { Starting } \\
\text { Pen Weight }^{2} \\
(\mathrm{~kg})\end{array}$ & $\begin{array}{c}\text { Day 3-21 } \\
\text { Pen Feed } \\
\text { Intake (kg) }\end{array}$ & $\begin{array}{c}\text { Day 3-21 } \\
\text { FCR }^{3} \\
(\mathrm{~kg} / \mathrm{kg})\end{array}$ & $\begin{array}{c}\text { Day 3-21 } \\
\text { LWG }^{4} \\
(\mathrm{~kg})\end{array}$ & $\begin{array}{c}\text { Percent } \\
\text { Mortality (\%) }\end{array}$ & $\begin{array}{l}\text { Tibia Ash } \\
\text { (mg/chick) }\end{array}$ & $\begin{array}{c}\text { Tibia Ash } \\
(\%)\end{array}$ \\
\hline $\begin{array}{c}\mathrm{NC} \\
\left(0.28 \mathrm{nPP}^{5}\right)\end{array}$ & 0.410 & $3.20^{\mathrm{d}}$ & $1.71^{\mathrm{a}}$ & $0.261^{\mathrm{d}}$ & $15.62^{\mathrm{a}}$ & $330.26^{\mathrm{e}}$ & $21.71^{\mathrm{d}}$ \\
\hline $\begin{array}{c}\text { 1PC:3NC } \\
(0.32 \text { nPP })\end{array}$ & 0.408 & $4.89^{\mathrm{c}}$ & $1.50^{\mathrm{b}}$ & $0.413^{\mathrm{c}}$ & $4.68^{b}$ & $454.70^{\mathrm{d}}$ & $25.36^{\mathrm{c}}$ \\
\hline $\begin{array}{l}\text { 3PC:1NC } \\
(0.35 \text { nPP) }\end{array}$ & 0.408 & $5.23^{\mathrm{a}}$ & $1.45^{\mathrm{b}}$ & $0.463^{\mathrm{a}}$ & $3.12^{\mathrm{b}}$ & $584.82^{\mathrm{bc}}$ & $29.83^{\mathrm{ab}}$ \\
\hline $\begin{array}{c}\text { PC } \\
(0.41 \text { nPP })\end{array}$ & 0.408 & $5.09^{\mathrm{bc}}$ & $1.49^{\mathrm{b}}$ & $0.446^{\mathrm{abc}}$ & $3.12^{\mathrm{b}}$ & $598.87^{\text {bc }}$ & $30.60^{\mathrm{a}}$ \\
\hline $\begin{array}{c}\text { NC+B1- } 250 \\
\text { FTU/kg }\end{array}$ & 0.408 & $4.93^{b c}$ & $1.52^{\mathrm{b}}$ & $0.422^{\mathrm{bc}}$ & $4.68^{b}$ & $470.75^{d}$ & $25.83^{\mathrm{c}}$ \\
\hline $\begin{array}{c}\text { NC+B1- } 500 \\
\text { FTU/kg } \\
\end{array}$ & 0.408 & $5.24^{\mathrm{b}}$ & $1.49^{\mathrm{b}}$ & $0.452^{\mathrm{abc}}$ & $3.12^{\mathrm{b}}$ & $555.30^{c}$ & $28.50^{b}$ \\
\hline $\begin{array}{c}\text { NC+B1- } 750 \\
\text { FTU/kg }\end{array}$ & 0.407 & $5.35^{\mathrm{ab}}$ & $1.47^{\mathrm{b}}$ & $0.459^{\mathrm{ab}}$ & $1.56^{\mathrm{b}}$ & $606.45^{b}$ & $30.48^{\mathrm{a}}$ \\
\hline $\begin{array}{c}\text { NC+B1- } 1000 \\
\text { FTU/kg }\end{array}$ & 0.408 & $5.61^{\mathrm{a}}$ & $1.47^{\mathrm{b}}$ & $0.481^{\mathrm{a}}$ & $1.56^{\mathrm{b}}$ & $660.2^{\mathrm{a}}$ & $31.31^{\mathrm{a}}$ \\
\hline $\begin{array}{c}\text { ANOVA } \\
\text { P-value }\end{array}$ & 0.4123 & $<0.0001$ & $<0.0001$ & $<0.0001$ & 0.0022 & $<0.0001$ & $<0.0001$ \\
\hline SEM $^{6}$ & 0.0008 & 0.1025 & 0.0316 & 0.0140 & 2.341 & 16.129 & 0.5205 \\
\hline $\begin{array}{c}\text { Fisher's } \\
\text { LSD }^{7}\end{array}$ & ------- & 0.2914 & 0.0900 & 0.0398 & 6.65 & 45.839 & 1.4792 \\
\hline
\end{tabular}

${ }^{1}$ Treatments $0.28,0.33,0.41,0.43$ describes the calculated non-phytate phosphorus percentage. Enzyme B1 was the chosen enzyme/host combination from Experiment 3 .

Goal enzyme concentration for each treatment was $250,500,750$, or $1000 \mathrm{FTU} / \mathrm{kg}$.

${ }_{3}^{2}$ Starting pen weight based on 8 birds per pen

Feed Conversion Ratio (Feed:Gain) was calculated using mortality weight

${ }_{5}^{4}$ Live Weight Gain

${ }^{5}$ Non-phytate phosphorus is calculated by total phosphorus - $(0.282 \mathrm{X}$ phytic acid $)$

${ }^{5}$ Standard Error of the Mean

Fisher's Least Significant Difference

${ }^{\text {a-e }}$ Means within a column not sharing a common superscript differ $(\mathrm{P}<0.05)$ 
57 Table 9. Experiment 3: in vivo dosing assay using the best enzyme/host combination chosen from Experiment 3.

58 Sparing Effects calculated from standard curve quadratic regression using tricalcium phosphate.

\begin{tabular}{|c|c|c|c|c|c|c|c|c|c|c|}
\hline Treatment $^{1}$ & $\begin{array}{c}\text { Quadratic } \\
\text { derived Calc } \\
\text { nPP }(\%) \\
\text { LWG }^{2}(\mathbf{k g})\end{array}$ & $\begin{array}{c}\text { LWG (kg) } \\
\text { nPP } \\
\text { Sparing } \\
\text { Effect }^{3}\end{array}$ & $\begin{array}{c}\text { Quadratic } \\
\text { derived Calc } \\
\text { nPP }(\%) \text { Pen } \\
\text { Feed Intake }^{4}\end{array}$ & $\begin{array}{c}\text { Pen Feed } \\
\text { Intake nPP } \\
\text { Sparing } \\
\text { Effect }^{3}\end{array}$ & $\begin{array}{c}\text { Quadratic } \\
\text { derived Calc } \\
\text { nPP }(\%) \\
\text { FCR }^{5}\end{array}$ & $\begin{array}{c}\text { FCR nPP } \\
\text { Sparing } \\
\text { Effect }^{3}\end{array}$ & $\begin{array}{c}\text { Quadratic } \\
\text { derived Calc } \\
\text { nPP }(\%) \text { Tibia } \\
\text { Ash Percent }^{6}\end{array}$ & $\begin{array}{c}\text { Tibia Ash } \\
\text { Percent } \\
\text { Sparing } \\
\text { Effect }^{3}\end{array}$ & $\begin{array}{c}\text { Quadratic } \\
\text { derived Calc } \\
\text { nPP }(\%) \text { Tibia } \\
\text { Ash mg/chick }{ }^{7}\end{array}$ & $\begin{array}{c}\text { Tibia Ash } \\
\text { mg/chick } \\
\text { Sparing } \\
\text { Effect }^{3}\end{array}$ \\
\hline $\begin{array}{c}\text { NC+B1 - } 250 \\
\text { FTU/kg }\end{array}$ & 0.31 & 0.03 & 0.31 & 0.03 & 0.30 & 0.02 & 0.30 & 0.02 & 0.30 & 0.02 \\
\hline $\begin{array}{c}\text { NC+B1 - } 500 \\
\text { FTU/kg }\end{array}$ & 0.33 & 0.05 & 0.33 & 0.05 & 0.31 & 0.03 & 0.35 & 0.07 & 0.36 & 0.08 \\
\hline $\begin{array}{c}\text { NC+B1 - } 750 \\
\text { FTU/kg }\end{array}$ & 0.34 & 0.06 & 0.34 & 0.06 & 0.32 & 0.04 & 0.42 & 0.14 & 0.40 & 0.12 \\
\hline $\begin{array}{c}\text { NC+B1 - } 1000 \\
\text { FTU/kg }\end{array}$ & 0.38 & 0.10 & 0.35 & 0.07 & 0.32 & 0.04 & 0.48 & 0.20 & 0.48 & 0.20 \\
\hline
\end{tabular}

$59 \quad{ }^{1}$ Enzyme $\mathrm{C} 1$ was the chosen enzyme/host combination from Experiment 3

$60{ }^{1}$ Calculated $\mathrm{nPP}$ values derived from the quadratic regression of LWG percent for the standard curve

$61\left[-9.2687 \pm \sqrt{9.2687^{2}-4(-12.128)(-1.29-L W G)}\right] / 2(-12.128)=$ calc. $\mathrm{nPP}, \mathrm{R}^{2}=0.76$

62 Sparing effect based on tricalcium phosphate

$63{ }^{3}$ Calculated nPP values derived from the quadratic regression of Pen Feed Intake percent for the standard curve

$64\left[-99.70 \pm \sqrt{99.70^{2}-4(-131.69)(-13.39-P F I)}\right] / 2(99.70)=$ calc. $n P P, R^{2}=0.85$

$65{ }^{4}$ Calculated nPP values derived from the quadratic regression of FCR percent for the standard curve

$66\left[13.09 \pm \sqrt{-13.09^{2}-4(17.44)(3.88-F C R)}\right] / 2(17.44)=$ calc. $\mathrm{nPP}, \mathrm{R}^{2}=0.55$

$67{ }^{5}$ Calculated nPP values derived from the quadratic regression of Tibia Ash \% percent for the standard curve

$68 \quad\left[-267.66 \pm \sqrt{267.66^{2}-4(-354.36)(-21.14-\text { Tibia Ash Percent })}\right] / 2(-354.36)=$ calc. $n P P, R^{2}=0.51$

$69{ }^{6}$ Calculated $\mathrm{nPP}$ values derived from the quadratic regression of Tibia Ash mg/chick percent for the standard curve

$70 \quad\left[-9970.18 \pm \sqrt{9970.18^{2}-4(-12533.67)\left(-1384.87-\text { Tibia Ash } \frac{\mathrm{mg}}{\text { chick }}\right)}\right] / 2(-12533.67)=$ calc. $n P P, R^{2}=0.79$ 
Table 10. Experiment 4: The effect of phytase enzymes in pelleted feed on live bird performance

\begin{tabular}{|c|c|c|c|c|c|c|c|}
\hline Treatment ${ }^{1}$ & $\begin{array}{c}\text { Day } 3 \\
\text { Starting Pen } \\
\text { Weight }^{2}(\mathrm{~kg})\end{array}$ & $\begin{array}{c}\text { Day 3-21 } \\
\text { Pen Feed } \\
\text { Intake (kg) }\end{array}$ & $\begin{array}{c}\text { Day 3-21 } \\
\text { FCR }^{3} \\
(\mathrm{~kg} / \mathrm{kg})\end{array}$ & $\begin{array}{c}\text { Day 3-21 } \\
\text { LWG }^{4}(\mathrm{~kg})\end{array}$ & $\begin{array}{c}\text { Percent } \\
\text { Mortality } \\
(\%)\end{array}$ & $\begin{array}{c}\text { Tibia Ash } \\
\text { (mg/chick) }\end{array}$ & $\begin{array}{c}\text { Tibia Ash } \\
(\%)\end{array}$ \\
\hline $\begin{array}{c}\mathrm{NC} \\
\left(0.24 \mathrm{nPP}^{5}\right) \\
\end{array}$ & 0.465 & $3.20^{\mathrm{e}}$ & $1.90^{\mathrm{a}}$ & $0.154^{\mathrm{d}}$ & 4.68 & $290.75^{\mathrm{c}}$ & $22.83^{c}$ \\
\hline $\begin{array}{l}\text { 1PC:3NC } \\
(0.30 \text { nPP })\end{array}$ & 0.464 & $4.90^{\text {cd }}$ & $1.52^{\mathrm{bcd}}$ & $0.362^{\mathrm{c}}$ & 4.68 & $462.12^{\mathrm{b}}$ & $26.82^{\mathrm{ab}}$ \\
\hline $\begin{array}{l}\text { 3PC:1NC } \\
(0.35 \text { nPP) }\end{array}$ & 0.463 & $5.24^{\mathrm{c}}$ & $1.40^{\mathrm{def}}$ & $0.427^{\mathrm{ab}}$ & 1.56 & $585.36^{\mathrm{a}}$ & $29.59^{\mathrm{a}}$ \\
\hline $\begin{array}{c}\text { PC } \\
(0.41 \text { nPP }) \\
\end{array}$ & 0.463 & $5.09^{\text {cd }}$ & $1.35^{\mathrm{ef}}$ & $0.427^{\mathrm{ab}}$ & 3.12 & $591.28^{\mathrm{a}}$ & $28.91^{\mathrm{a}}$ \\
\hline $\mathrm{NC}+\mathrm{B} 1-7^{\circ} \mathrm{C}$ & 0.464 & $5.86^{\mathrm{b}}$ & $1.48^{\text {cde }}$ & $0.447^{\mathrm{bc}}$ & 3.12 & $469.28^{\mathrm{b}}$ & $25.84^{\mathrm{b}}$ \\
\hline $\mathrm{NC}+\mathrm{B} 1-85^{\circ} \mathrm{C}$ & 0.462 & $6.74^{\mathrm{a}}$ & $1.62^{\mathrm{bc}}$ & $0.466^{\mathrm{a}}$ & 1.56 & $330.24^{c}$ & $20.99^{c}$ \\
\hline $\mathrm{NC}+\mathrm{B} 1-9^{\circ} \mathrm{C}$ & 0.465 & $6.53^{\mathrm{a}}$ & $1.67^{\mathrm{b}}$ & $0.436^{\mathrm{ab}}$ & 1.56 & $304.92^{c}$ & $22.78^{c}$ \\
\hline NC+B1- Mash & 0.465 & $4.67^{\mathrm{d}}$ & $1.29^{\mathrm{f}}$ & $0.418^{\mathrm{b}}$ & 4.68 & $631.62^{\mathrm{a}}$ & $29.20^{\mathrm{a}}$ \\
\hline $\begin{array}{c}\text { ANOVA } \\
\text { P-value }\end{array}$ & 0.4417 & $<0.0001$ & $<0.0001$ & $<0.0001$ & 0.9000 & $<0.0001$ & $<0.0001$ \\
\hline SEM $^{6}$ & 0.0011 & 0.1571 & 0.0582 & 0.0140 & 2.2981 & 2.2981 & 0.9826 \\
\hline $\begin{array}{c}\text { Fisher's } \\
\text { LSD }^{7}\end{array}$ & ------ & 0.4467 & 0.1654 & 0.0400 & ----- & 22.7765 & 2.7926 \\
\hline
\end{tabular}

${ }^{1}$ Treatments $0.28,0.33,0.41,0.43$ describes the calculated non-phytate phosphorus percentage. Enzyme $\mathrm{C} 1$ was chosen to be included in diets at $750 \mathrm{FTU} / \mathrm{kg}$ based on results from Experiment 4; the enzymes were pelleted at $75^{\circ} \mathrm{C}, 85^{\circ} \mathrm{C}, 90^{\circ} \mathrm{C}$. One treatment was not pelleted to be used as a control.

${ }^{2}$ Starting pen weight based on 8 birds per pen

$74 \quad$ Feed Conversion Ratio (Feed:Gain) was calculated using mortality weight

${ }_{5}^{4}$ Live Weight Gain

${ }^{5}$ Non-phytate phosphorus is calculated by total phosphorus $-(0.282 \mathrm{X}$ phytic acid $)$

${ }^{6}$ Standard Error of the Mean

${ }^{7}$ Fisher's Least Significant Difference

${ }^{\text {a-f }}$ Means within a column not sharing a common superscript differ $(\mathrm{P}<0.05)$ 
Table 11. Experiment 4: in vivo assay using increasing pelleting temperature. Sparing Effects calculated from standard curve quadratic regression using tricalcium phosphate.

\begin{tabular}{|c|c|c|c|c|c|c|c|c|c|c|}
\hline Treatment $^{1}$ & $\begin{array}{c}\text { Quadratic } \\
\text { derived Calc } \\
\text { nPP }(\%) \\
\text { LWG }^{2}(\mathbf{k g})\end{array}$ & $\begin{array}{c}\text { LWG (kg) } \\
\text { nPP } \\
\text { Sparing } \\
\text { Effect }^{3}\end{array}$ & $\begin{array}{c}\text { Quadratic } \\
\text { derived Calc } \\
\text { nPP }(\%) \text { Pen } \\
\text { Feed Intake }^{4}\end{array}$ & $\begin{array}{c}\text { Pen Feed } \\
\text { Intake nPP } \\
\text { Sparing } \\
\text { Effect }^{3}\end{array}$ & $\begin{array}{c}\text { Quadratic } \\
\text { derived } \\
\text { Calc nPP } \\
(\%) \text { FCR }^{5}\end{array}$ & $\begin{array}{c}\text { FCR nPP } \\
\text { Sparing } \\
\text { Effect }^{3}\end{array}$ & $\begin{array}{c}\text { Quadratic } \\
\text { derived Calc } \\
\text { nPP }(\%) \text { Tibia } \\
\text { Ash Percent }\end{array}$ & $\begin{array}{c}\text { Tibia Ash } \\
\text { Percent nPP } \\
\text { Sparing } \\
\text { Effect }^{3}\end{array}$ & $\begin{array}{c}\text { Quadratic } \\
\text { derived Calc } \\
\text { nPP }(\%) \text { Tibia } \\
\text { Ash mg/chick }\end{array}$ & $\begin{array}{c}\text { Tibia Ash } \\
\text { Percent nPP } \\
\text { Sparing } \\
\text { Effect }^{3}\end{array}$ \\
\hline $\mathrm{NC}+\mathrm{B} 1-7^{\circ} \mathrm{C}$ & 0.36 & 0.12 & 0.30 & 0.06 & 0.32 & 0.08 & 0.28 & 0.04 & 0.29 & 0.05 \\
\hline $\mathrm{NC}+\mathrm{B} 1-85^{\circ} \mathrm{C}$ & 0.33 & 0.09 & 0.26 & 0.02 & 0.28 & 0.04 & 0.22 & 0.00 & 0.25 & 0.01 \\
\hline $\mathrm{NC}+\mathrm{B} 1-90^{\circ} \mathrm{C}$ & 0.36 & 0.12 & 0.27 & 0.03 & 0.28 & 0.04 & 0.24 & 0.00 & 0.24 & 0.00 \\
\hline NC+B1 - Mash & 0.34 & 0.10 & 0.29 & 0.05 & 0.35 & 0.11 & 0.36 & 0.12 & 0.35 & 0.11 \\
\hline
\end{tabular}

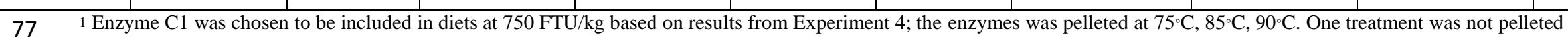

78 to be used as a control.

$79{ }^{2}$ Calculated nPP values derived from the quadratic regression of LWG percent for the standard curve

$80 \quad\left[-10.738 \pm \sqrt{10.738^{2}-4(-14.037)(-1.614-L W G)}\right] / 2(-14.037)=$ calc. $\mathrm{nPP}, \mathrm{R}^{2}=0.86$

$81 \quad$ Sparing effect based on tricalcium phosphate

$82{ }^{4}$ Calculated nPP values derived from the quadratic regression of Pen Feed Intake percent for the standard curve

$83\left[-94.04 \pm \sqrt{94.04^{2}-4(-127.65)(-12.01-P F I)}\right] / 2(-127.65)=$ calc. $n P P, R^{2}=0.89$

$84{ }^{5}$ Calculated nPP values derived from the quadratic regression of FCR percent for the standard curve

$85 \quad\left[17.27 \pm \sqrt{-17.27^{2}-4(21.52)(4.81-F C R)}\right] / 2(21.52)=$ calc. $n P P, R^{2}=0.59$

$86{ }^{6}$ Calculated nPP values derived from the quadratic regression of Tibia Ash Percent for the standard curve

$87 \quad\left[-267.66 \pm \sqrt{267.66^{2}-4(-354.36)(-21.14-\text { Tibia Ash Percent })}\right] / 2(-354.36)=$ calc. $n P P, R^{2}=0.5105$

$88{ }^{7}$ Calculated $\mathrm{nPP}$ values derived from the quadratic regression of Tibia Ash $\mathrm{mg} / \mathrm{chick}$ percent for the standard curve

$89\left[-9970.18 \pm \sqrt{9970.18^{2}-4(-12533.67)(-1384.87-\text { Tibia Ash mg/chick })}\right] / 2(-12533.67)=$ calc. $n P P, \mathrm{R}^{2}=0.7972$ 
90 Figure 1. In vitro phytase retention of pellets conditioned at $75,80,85,88,90,93^{\circ} \mathrm{C}$ containing enzymes $\mathrm{A}-\mathrm{D}$ (utilized 91 in Experiment 1) using the AOAC 2000.12 method

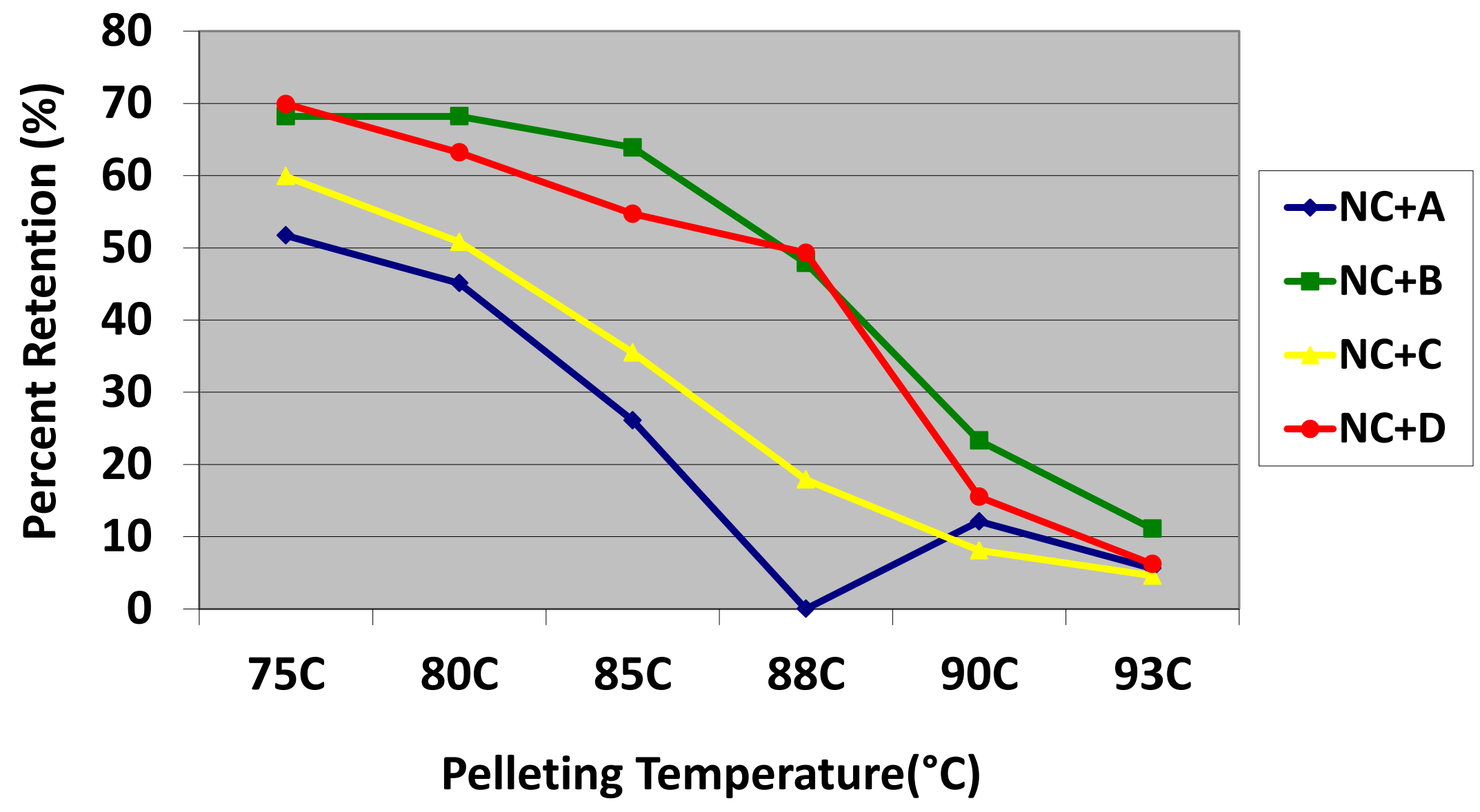


Figure 2. In vitro phytase retention of pellets conditioned at $75,80,85,88,90,93^{\circ} \mathrm{C}$ containing enzymes $\mathrm{B}, \mathrm{C}, \mathrm{B} 1, \mathrm{C1}$ (utilized in Experiment 2) using the AOAC 2000.12 method

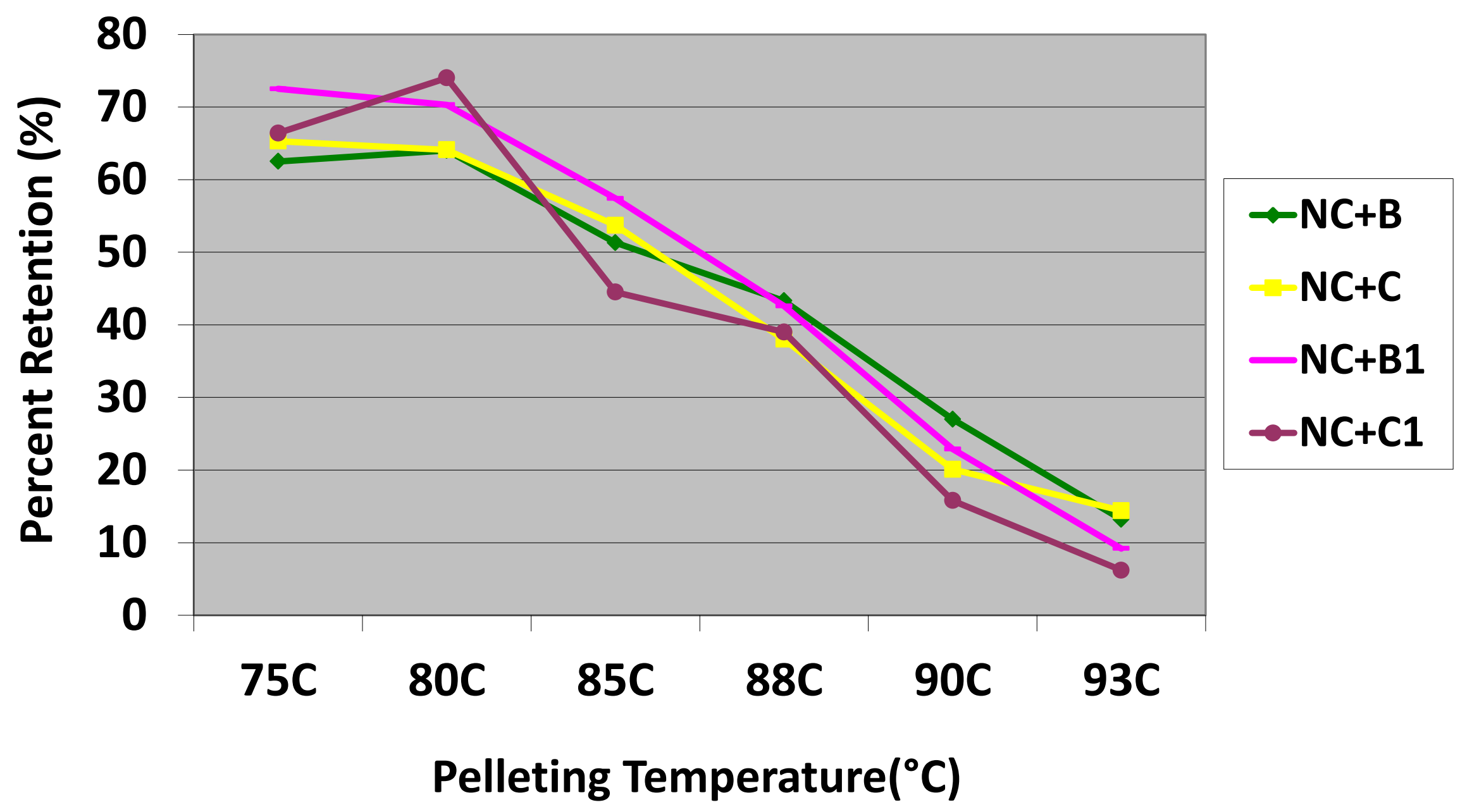


CIRRICULUM VITAE

97

Ashley M. Evans

$98 \cdot 1023 B$ College Ave. Morgantown, WV 26505

· aevans6@mix.wvu.edu $•$

(304) $257-0246^{\circ}$

99 Enthusiastic and works well within a team, but also proficient working as an individual. Not foreign to hard-work

100 and thrives under pressure.

101 Goal: To obtain research experience in poultry production and non-ruminant nutrition. I hope to gain a wealth of

102 poultry knowledge spanning from feed manufacturing to organic poultry production. I plan to continue participating

103 in research and to one day educate and inspire others in the area of poultry science.

104

105

\section{EDUCATION}

106 Degree earned: Bachelors of Science, Animal and Nutritional Science; May 2010

107 Undergraduate GPA: 3.15

108

109

110

111

112

113

114

Expected Degree: Masters of Science, Animal and Food Science

Expected Graduation Date: May 2012

Current GPA: 3.37

115

Graduated from Moorefield High School in 2006:

116

117

118

119

120

121

122

123

124

125

126

127

- President's Academic Award

- Top of the Mountain Award

- National Honor Society Member, Moorefield High School Chapter (2004-2006)

- Girl's Tennis Team Member (2006)

\section{Scholarships/Grants Received:}

- Promise Scholarship (2006-2007)

- AACU Scholarship (2006-2007)

- Mountaineer Scholarship (2006-2007)

- PELL Grant (2007-2010)

- $\quad$ SMART Grant (2007-2010)

- West Virginia Higher Education Grant (2007-2010)

Awards and Honors:

129

130

131

\section{First Author Publications:}

Abstracts 
A.M. Evans, K.D. Baldock, D.L. Smith, and J.S. Moritz. 2012. Algae biomass as energy source for animal feeds. Poult. Sci. (Accepted Abstract).

\section{Co-author Publications:} Abstracts

K.J. Shipe, A.M. Evans, K.G.S Lilly, L.K. Shires, B.N. Swiger, and J.S.Moritz. 2011. Effects of feed manufacture techniques that vary feed exposure to pellet die heat and pressure on pellet quality and subsequent broiler lysine utilization. Poult.Sci. (Accepted Abstract).

K.G.S. Lilly, L.K. Shires, B.N. Swiger, A.M. Evans, K.J. Shipe, and J.S. Moritz. 2011. Resolving pellet quality issues and improving turkey poult performance with the manufacture of commercial turkey diet formulations. 2011 Poult.Sci. (Accepted Abstract).

L.K. Shires, B.N. West, K.G.S. Lilly, A.M. Evans and J.S. Moritz. 2011. The effects of early feed amino acid and late feed non-phytate phosphorus levels on large tom performance, yield, and litter composition. Poult.Sci. (Accepted Abstract).

L.K. Shires, K.G.S. Lilly, B.N. Swiger, A.M. Evans and J.S. Moritz. 2011. The effect of marine and flaxseed oil inclusion in diets for pastured laying flocks on EPA, DHA, and consumer acceptability of eggs. Poult.Sci. (Accepted Abstract).

K.G.S. Lilly, L.K. Shires, B.N. Swiger, A.M. Evans, K.J. Shipe, and J.S. Moritz. 2011. Manufacturing techniques to improve pellet quality of commercial turkey diet formulations and six week male poult performance. $18^{\text {th }}$ European Symposium on Poultry Nutrition.(Accepted Abstract \& Full Text Submission). Presentation was in Cesme- Izmir, Turkey. November 2011.

\section{National Meeting Paper Presentations}

- 2011 Poultry Science Association (St. Louis, MI) (Graduate Student)

"The effects of early feed amino acid and late feed non-phytate phosphorus levels on large tom performance, yield, and litter composition"

\section{Graduate Teaching Assistant (M.S.)}

\section{Fall 2010 - Present}

- Teaching Assistant for Companion Animals Class (Role includes lecturing occasionally in class) (A\&VS 275)

- Teaching Assistant for Advanced Animal Nutrition (Role includes lecturing occasionally in class) (ANNU 362)

\section{Graduate Research Assistant (M.S.)}

\section{Fall 2010 - Present}

- Led five contract studies with Verenium Corp. utilizing four phytase enzyme variants and different testing variables (Spring and Summer 2011, Spring 2012)

- Led eight contract studies with Verenium Corp. utilizing xylanase and glucanase enzyme variants and different concentrations and their effects on energy utilization in single comb white leghorn roosters (Spring and Summer 2011) 
- Presented research to Verenium Corp. in San Diego, Ca. (7/21-7/24/2011)

- Contract Studies with JBS United, Enzivia, Phytex, Poet Nutrition, Virginia Poultry Grower's Coop

- Contract Pelleting Studies with JBS United and Phytex

- Assist with Veterinary Technician classes to help the students learn about poultry and teach them to efficiently draw blood from poultry

- Organizer and Poultry Judge for Career Development Events (9/22/2010, 9/23/2011)

- Preston County Kids Day Fair Poultry Presentation

- Assist with planning for WV Poultry Week, state fair activities (2/16/2011)

- Attended Grazing Conference (3/4/2011)

- Preston County Kid's Safety Day (6/4/2011)

- Assisted with WV poultry week activities (7/26-7/27/2011)

- Assisted with Poultry Workshop at WVU Organic Field Day (8/4/2011)

- Assisted with activities and displays (birds and poster) for Monongalia County and WV State Fair (Summer 2011)

- Guest Lecturer for Intro to Animal Science Course

- Assisted with Tiger Cub Farm Visit (11/28/2011)

- Guest lecturer at Eastern New Mexico University (12/2/2011)

- Led the chick brooder section of a broiler processing workshop for small farm producers $(3 / 1 / 2012)$
Moorefield Church of the Brethren
- Help teach Sunday School class
1995 - present
- Prepare and direct Sunday School class Christmas Play
- Door greeter
- Help collect offerings
- Occasional participate in choral activities

\section{EXPERIENCE}

West Virginia Department of Highways

2007 - 2010

- Temporary/summer employment

- Main flagger for both primary and secondary road crews

- Animal removal from highway

- Assisted with various office tasks, including payroll, entrance permits, and employee records

- Assisted with fiscal year-end inventory

Veterinary Hospital Volunteer

$2003-2009$

- Assisted with various surgeries

- Filled prescriptions

- Ran fecal analysis

- Handled pets and cleaned their cage

\section{SKILLS}

- Proficient in Window's Microsoft Programs

- Internet Literate

- Poultry Handling, Judging, and Husbandry 
221

222

223

224

225

226

227

228

229

230

231

232

233

234

235

236

237

238

239

240

241

242

- Feed Manufacture and Diet Formulation

- Precision-feeding

- Cecectomy Surgery

- Tibia and Ileum Extraction

- Experience with Brookfield Viscometer

- Experience with R statistical program and SAS

- Agricultural/Animal specific courses taken:

-Animal Nutrition 260 \& 360

-Animal Nutrition 362

-Poultry Production 367\& Lab 369

-Environmental Microbiology 341

-Poultry Judging 338

- Companion Animal Science 275

-Veterinary Anatomy 401

-Alpaca Production 273

-Animal Physiology 301

-Reproductive Physiology 424

-Behavior Patterns of Animals 480

-Biochemistry 410

Graduate Courses:

-Applied Water Microbiology 508

-Statistics 511,512,513

-Animal Biotechnology 514

-Food Microbiology 545

-General Biochemistry 610

-Nutritional Biochemistry 512 